\title{
31. CARBON AND OXYGEN ISOTOPE RECORDS AT DSDP SITE 384 (NORTH ATLANTIC) AND SOME PALEOCENE PALEOTEMPERATURES AND CARBON ISOTOPE VARIATIONS IN THE ATLANTIC OCEAN
}

\author{
Anne Boersma, Lamont Geological Observatory, Palisades, New York \\ and \\ Nicholas Shackleton, Mike Hall, and Quentin Given, Sub-Department of Quaternary Research, \\ Cambridge University, Cambridge, England
}

\begin{abstract}
Detailed analysis of over 200 samples of uppermost Cretaceous and Paleocene sediments from Atlantic Ocean DSDP Sites 384, 86, 95, 152, 144, $20 \mathrm{C}, 21,356,357$, and 329 provides new information on the temperature stratification of Paleocene planktonic foraminifera, the temperature and carbon isotopic changes across the Cretaceous/Tertiary boundary, and the fluctuating temperature and carbon isotopic records through the Paleocene ( $64.5-54$ m.y.).

There was a significant temperature rise across the Cretaceous/Tertiary boundary both at the surface and in deep waters of the Atlantic Ocean. This temperature rise occurred before the basal Tertiary "Globigerina" eugubina Zone, so that in the oldest Paleocene sample yet analyzed from the deep sea (Site 356) temperatures are already three degrees higher at the bottom and at the surface than in the Cretaceous. The temperature rise across the boundary is more pronounced on the bottom and in samples from higher latitudes.

Accompanying the temperature rise across the boundary there is a significant shift in the carbon isotope profile. In the basal Paleocene the foraminifera of the surface zone demonstrate very negative carbon isotope values (unlike in the Cretaceous of today's ocean), while deeper dwelling species have more positive values which then decrease to the bottom. The unusual carbon isotope gradients persist through the first three million years of the Paleocene until towards the top of planktonic foraminiferal Zone P.1 (G. trinidadensis Zone) the foraminifera record a profile more positive at the surface and decreasing towards the bottom (as in today's ocean).

During the Paleocene there are two noteworthy rises in surface water temperature; the first around 62-61 m.y. (G. trinidadensis Zone), and the second near the base of the Globorotalia angulata Zone, 60-59 m.y. At this time surface temperatures at low to mid latitudes reached values near $25^{\circ} \mathrm{C}$, while at mid-latitude Site 384 temperature highs near $22^{\circ} \mathrm{C}$ were registered. At a sample spacing of around one per million years, we have only produced some of the detail of these temperature fluctuations. The later Paleocene is generally cooler and there do not seem to be any large variations either through time or latitude. Middle-latitude sites average temperatures near $15^{\circ} \mathrm{C}$ at the surface, while high lower latitude site temperatures range near $18^{\circ} \mathrm{C}$.

The most salient feature of the bottom temperature record (based on multispecific samples) through the Paleocene is its lack of fluctuations. There is an overall temperature range of $5^{\circ} \mathrm{C}$ at these intermediate depth sites (paleodepth estimates between 1500 and $3000 \mathrm{~m}$ ). Higher values near $13^{\circ} \mathrm{C}$ accompany the surface temperature peaks around 62 and $60 \mathrm{~m} . \mathrm{y}$. , while low values near $8^{\circ} \mathrm{C}$ occur in Zone P.2 (61-60 m.y.). We detected no change in bottom temperature across the paleocene/Eocene boundary in the few samples studied so far.

While there are several fluctuations in the carbon isotope values through the early Paleocene, the general trend is one of increasingly positive values at the surface and at depth. This trend culminates in the late Paleocene (upper Zone P.4, about 56-57 m.y.) with a major excursion in the carbon isotope values. At low latitudes the range between the surface and the deepest planktonic foraminifera is a $\delta^{13} \mathrm{C}$ of $4 \%$ as compared with a range of $2 \%$ today. The carbon values drop off slightly, but remain strongly positive through the remainder of the Paleocene at most sites. Accompanying the carbon isotope excursion at Site 384 is a productivity increase and a proposed rise in the CCD.
\end{abstract}




\section{INTRODUCTION}

There is very little available information about the temperature or carbon isotope record at the very base of the Tertiary, following the uppermost Cretaceous series of extinctions in the ocean's surface waters. We have undertaken to produce detailed carbon and oxygen isotopic records through the Paleocene (about 64.5 to 54 m.y.). We have made over 200 carbon and oxygen isotope analyses on the carbonate tests of both planktonic and benthic foraminifera from DSDP Site 384 and from others in the equatorial and southern Atlantic Ocean (Table 1).

We examined the Atlantic Ocean closely in order to monitor the re-equilibration of oceanic ecosystems following the major disruption of the existing biologic and chemical balances at the end of the Cretaceous. Several questions about this process seemed particularly interesting: for example, what were the temperature characteristics of the oceanic surface waters following the extinction of most of their included biota? Were these temperatures higher or lower than temperatures of the latest Cretaceous? How and where did those planktonic organisms which survived do so? How did the ocean evolve in order to allow the re-radiation of its planktonic faunas through the course of the $\mathrm{Pa}$ leocene? What and when were the climatic changes during the course of the Paleocene? How did these alter key oceanic characteristics or affect the re-establishment of the planktonic biomass? What parameters on the bottom allowed the deep benthos to continue almost unchanged from the Cretaceous into the Tertiary, and what oceanic parameters changed which resulted in changing biogeographic patterns of the benthos during the Paleocene? What were the distributions of carbon and oxygen in the water column at the beginning of the Tertiary, and how did these distributions fluctuate during the Paleocene?

In order to investigate some of these questions we have attempted to produce the following:

1) the stratification order of Paleocene planktonic foraminifera in the water column;

2) a record of surface temperatures through the Paleocene;

3) the bottom temperature record through the $\mathrm{Pa}$ leocene;

TABLE 1

Drill Sites From Which We Have Made Isotopic Determinations

\begin{tabular}{lccc}
\hline Site & Latitude & Longitude & $\begin{array}{c}\text { Depth } \\
(\mathrm{m})\end{array}$ \\
\hline $20 \mathrm{C}$ & $28^{\circ} 31.57^{\prime} \mathrm{S}$ & $26^{\circ} 50.73^{\prime} \mathrm{W}$ & 4506 \\
21 & $28^{\circ} 35.10^{\prime} \mathrm{S}$ & $30^{\circ} 35.85^{\prime} \mathrm{W}$ & 2117 \\
47 & $32^{\circ} 26.90^{\prime} \mathrm{N}$ & $157^{\circ} 42.7^{\prime} \mathrm{W}$ & 2689 \\
94 & $24^{\circ} 31.64^{\prime} \mathrm{N}$ & $88^{\circ} 28.16^{\prime} \mathrm{W}$ & 1793 \\
95 & $24^{\circ} 09.00^{\prime} \mathrm{N}$ & $86^{\circ} 23.85^{\prime} \mathrm{W}$ & 1633 \\
144 & $09^{\circ} 27.33^{\prime} \mathrm{N}$ & $54^{\circ} 20.52^{\prime} \mathrm{W}$ & 1752 \\
356 & $28^{\circ} 17.22^{\prime} \mathrm{S}$ & $41^{\circ} 05.28^{\prime} \mathrm{W}$ & 3175 \\
357 & $30^{\circ} 00.25^{\prime} \mathrm{S}$ & $35^{\circ} 33.59^{\prime} \mathrm{W}$ & 2086 \\
384 & $40^{\circ} 21.65^{\prime} \mathrm{N}$ & $51^{\circ} 39.80^{\prime} \mathrm{W}$ & 3910 \\
\hline
\end{tabular}

4) the carbon isotopic records from these same samples through the Paleocene.

1) In order to construct a surface temperature curve it is necessary to know which foraminifera lived closest to the ocean surface. In a thermally stratified ocean species recording the warmest temperatures are considered to live closest to the surface. Therefore, in most samples all important planktonic foraminifera were analyzed. Knowing the temperature stratification of the planktonics, however, cannot tell us the depth at which each lived, and this is a major hindrance in this method.

The temperature gradient between the shallowest and deepest planktonic species can indicate characteristics of and the relative "strength" of the thermocline layer, which in turn is influencing the distribution of plankton. Aspects of functional morphology, rate and direction of evolution, and paleobiogeography can be interpreted on the basis of the vertical temperature structure in the water column.

As the stratification order generally parallels solution susceptibility, the latter can be estimated from the former. In conjunction with the carbon isotopic profiles, the oxygen profiles can suggest some of the distinctive habitats occupied by a species, for example, the thermocline layer, photic zone, or oxygen-minimum zone. In addition, records of intermediate depth groups can be compared with the record at the bottom to produce an indication of the character of oceanic deep water.

2) Knowing which foraminifera inhabit the surface zone allows us to use those species to produce a surface temperature record. This record can be used to interpret paleocirculation patterns, meridional temperature gradients, and hence paleoclimate. And only from such surface temperature values can climatic modeling be attempted and heat budgets be derived.

3) Most sites analyzed have estimated paleodepths in the range 2000 to 3000 meters. Knowing the temperature of intermediate depth water masses, particularly in mid latitudes, allows speculation on the flux and flow of oceanic deep waters, as well as on the character and geographic distribution of true bottom waters.

As is the case with surface waters, a knowledge of the temperature history of the deep water can aid in pinpointing times of removal of barriers to deep flow, in viewing climatic changes, and in interpreting some of the biogeographic patterns of the associated organisms.

4) By tracing the variations in the isotopic ratios of carbon through space and time, we derive information on the distribution of carbon in the ocean, the mass input of carbon to the ocean, and its partitioning. Briefly, variations in bottom carbon isotopic values over large geographic distances may indicate the course of deep water masses, the related nutrient, oxygen and $\mathrm{CO}_{3}$ content of these waters. Surface carbon ratios can indicate the extent of surface water productivity. Surface to bottom gradients can suggest the character and intensity of the oxygen-minimum zone, the oxygen distribu- 
tion through the water column, as well as changes in the oceanic carbon reservoir. These possibilities will be discussed in a later section.

\section{SCENARIO}

\section{Foraminifera}

The Paleocene encompasses the time from the Cretaceous/Tertiary boundary ( 64 m.y.) to the Eocene (54 m.y.). The end of the Cretaceous was characterized by major extinctions in oceanic plankton (including all but one planktonic foraminiferal species, shelf benthos, terrestrial faunas, particularly the dinosaurs) and floras. The majority of the deep benthos, however, survived across the boundary into the Paleocene. The earliest Paleocene (the Danian in European stage terminology) is a regressive period around the world. At the very base of the Danian tiny new planktonic foraminifera appear in the world oceans; these forms are miniscule $(40 \mu \mathrm{m})$ and not at all diverse. Gradually, during the course of the Danian, as the oceanic plankton re-established itself, the foraminifera increased in size and diversity. The late Paleocene (equivalent to the Thanetian Stage) is a transgressive interval along continental margins. During this time period many foraminiferal groups evolved and persisted into the Eocene.

Early Paleocene deep water benthic foraminifera are also generally small and less diverse than in the later Cretaceous. During the course of the Paleocene these forms increased in size and diversity and are thought to have migrated over large geographic and bathymetric ranges. A major taxonomic overturn occurred in the later Paleocene so that many new species characterize the faunas of the early and middle Eocene.

\section{Atlantic Paleogeography}

The Atlantic Ocean during the early Paleocene was composed of two elongate basins meeting at a narrow equatorial zone (Figure 1). Free circulation apparently connected the Caribbean and Mediterranean regions at low latitudes. While there was relatively little connection between the north Atlantic and the cooler Arctic regions, the South Atlantic was connected to the cooler sub-Antarctic regions of the South Atlantic and across the Aghulas Plateau into the Indian Ocean. Apparently, however, there was no circum-Antarctic current at this time, either at the surface or at depth, as the passage across the Falkland Plateau could be very shallow and there was no deep connection between Australia and Antarctica.

However, by the late Paleocene spreading in the North Atlantic along the Reykjanes Ridge system had opened a wider passage to the Arctic Ocean, and oceanic spreading to the north of Labrador had opened the passage there slightly, allowing a greater volume of Arctic waters to flow into the North Atlantic. No major change in bottom water flow from the south has been recorded in the Paleocene. The circumequatorial current (Tethys) persisted as the equatorial zone of the Atlantic widened through the course of the Paleocene.

\section{PREVIOUS WORK}

Great interest in the terminal events of the Cretaceous have caused many workers to focus their attention on that time period rather than on the initiation of the Tertiary. The oxygen isotope studies of Douglas and Savin $(1971,1973,1975)$ and Saito and van Donk (1974) resulted in a total of only 20 analyses of Paleocene foraminifera, from the North Pacific at low paleolatitudes (Sites 47 and 167) and from the South Atlantic and the Agulhas Plateau (Site 21, piston cores V2665 and V22-127).

Saito and van Donk (1974) presented evidence from analysis of single planktonic foraminiferal species of a temperature drop during the Late Cretaceous, and in particular near the Cretaceous/Tertiary boundary. They also show an "amelioration" early in the Paleocene. Douglas and Savin (1975), reviewing their data for this time interval, also conclude that temperatures in the equatorial Pacific decreased from the Late Cretaceous to the early Paleocene and recovered in the early Tertiary, although they regarded the magnitude of the changes as slight.

Douglas and Savin (1971) analyzed a sequence of samples from Site 47. They covered each Paleocene planktonic biozone, analyzing mixed planktonic species, and found very little change in oxygen isotopic composition, but a trend to higher ${ }^{13} \mathrm{C}$ content in the late Paleocene. Their benthic analysis is of a sample from Zone P.2.

Surface water temperatures calculated by Douglas and Savin for the equatorial Pacific through the Paleocene average about $18^{\circ} \mathrm{C}$. Saito and van Donk calculated a surface temperature of about $15^{\circ}$ on the Agulhas Plateau in the early Danian, and about $18^{\circ} \mathrm{C}$ on the Rio Grande Rise in the late Danian.

\section{PREMISES CONCERNING CARBON AND OXYGEN ISOTOPIC MEASUREMENTS}

The ${ }^{13} \mathrm{C} /{ }^{12} \mathrm{C}$ ratio is measured routinely at the same time as the oxygen isotopic ratios are determined. The methods used for these analyses as well as a fuller discussion of carbon in the oceans of the Pleistocene can be found in Shackleton (in press).

A simple model for the cycling of carbon in the oceans may be envisaged as a box (the ocean) with one input (bicarbonate ions entering from rivers) and two outlets in the ocean: to the sedimentary carbonate reservoir, and the stored organic carbon reservoir (including organic carbon, coal, and oil trapped in sedimentary deposits). While plants do obtain their carbon from the atmosphere, the carbon may be treated as originating in the river input to the oceans, since the atmosphere is in some sort of equilibrium with the oceans. To a first approximation the stored organic reservoir is consistently depleted in heavy carbon resulting in a $\delta^{13} \mathrm{C}$ of at least -20 per mil (Craig, 1953). The carbonate reservoir may for the present be treated as having the same isotopic composition as the oceanic carbon reservoir from which it is deposited (Broecker, 1971; Kroopnick et al., in press). Thus in this simple 


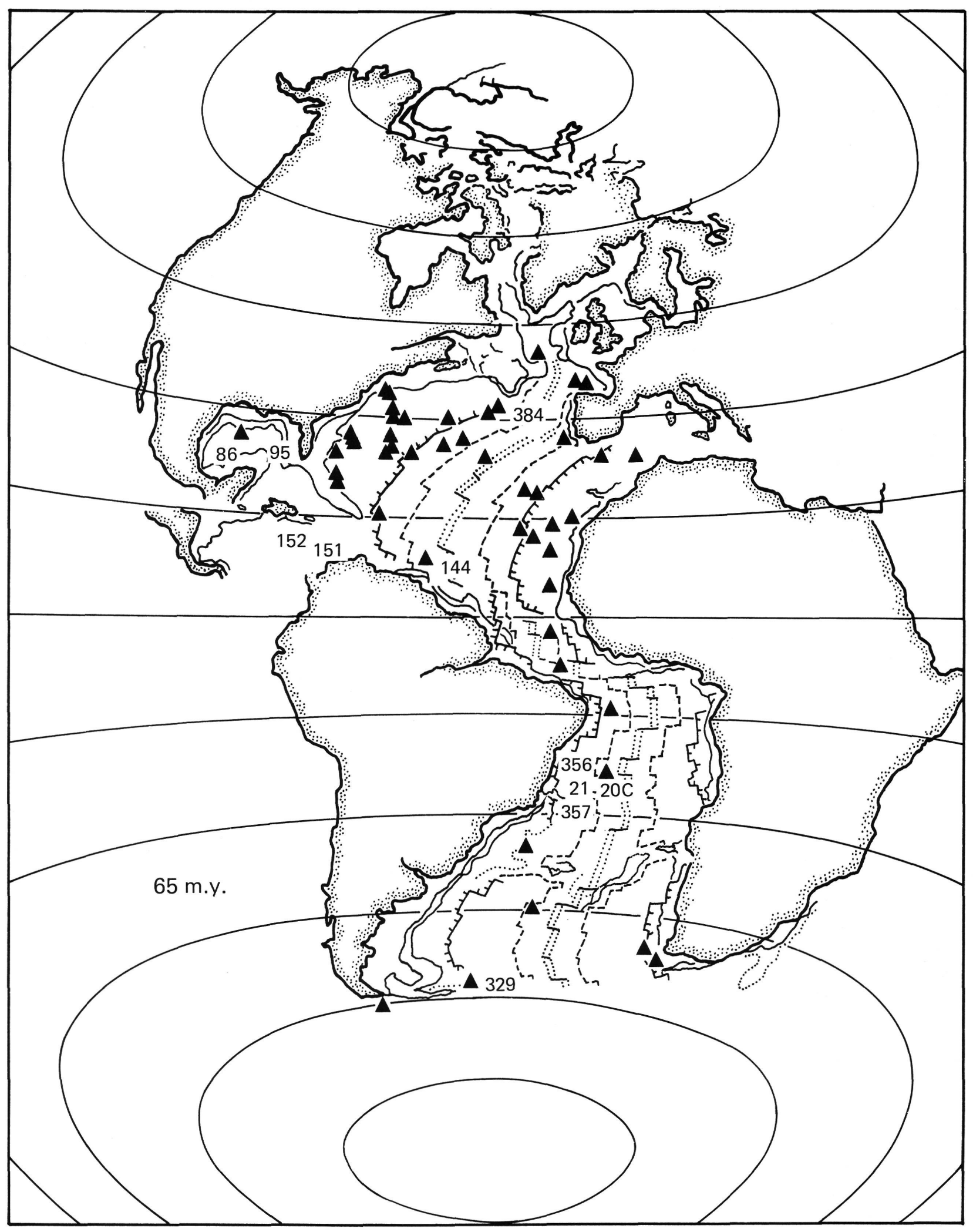

Figure 1. Paleobathymetric reconstruction of the Atlantic Ocean at $65 \mathrm{~m} . y$. , showing the locations of the DSDP sites included in this paper. 
model the oceanic carbon reservoir changes isotopic composition primarily in response to the changes in the partitioning of carbon taken into carbonate deposits and into stored organic carbon. In general, the response time of the source being eroded to provide the river input to balance any changes in the oceanic carbon will be significantly longer than the time scales considered here; thus restoration of the "theoretical" balance in the carbon isotope cycle will occur within the ocean itself.

Within the limits of this simple model, first one must consider separately the question of variations in the $\delta^{13} \mathrm{C}$ content of the oceanic dissolved carbon reservoir, and of regional variations in the $\delta^{13} \mathrm{C}$ content at one time. Variations in the $\delta^{13} \mathrm{C}$ content of the oceanic carbon reservoir can be understood only if (1) material from sufficient sites is available to establish that the variations are not local, and (2) the measurements are made using monospecific samples and preferably the same species through the interval over which the variation is being examined.

Variations in the oceanic $\delta^{13} \mathrm{C}$ may be of stratigraphic value as, for example, the negative $\delta^{13} \mathrm{C}$ excursion in the Pliocene noted by Shackleton and Kennett (1975) and the late Paleocene $\delta^{13} \mathrm{C}$ excursion discussed in this paper. In considering their origin, distinction must be made according to whether they are long or short compared with the residence time of $\mathrm{C}$ in the ocean (estimated by Broecker, 1974, as about $3 \times 10^{5}$ years for today's ocean). Shackleton (in press) has shown that during the Pleistocene, changes in terrestrial biomass gave rise to changes in the $\delta^{13} \mathrm{C}$ content of the ocean because they were so rapid $\left(10^{4}\right.$ year time scale) that the oceanic $\mathrm{C}$ reservoir was unable to return to its steady-state equilibrium $\delta^{13} \mathrm{C}$ content before another climatic event reversed the trend. However, on a long time scale compared with the $\mathrm{C}$ residence time in the oceans, changes in the $\delta^{13} \mathrm{C}$ content of the oceanic carbon reservoir could derive either from variations in the isotopic composition of the incoming carbon (not likely, as discussed above, for the time scales considered here) and/or from variations in partitioning, as posited above.

This gives an indication of the potential information in records of oceanic dissolved ${ }^{13} \mathrm{C}$. However, it must be appreciated that the overall ${ }^{13} \mathrm{C}$ range at a single site is similar in magnitude to the geographic variability in oceanic ${ }^{13} \mathrm{C}$ content, so that records from different ocean basins must be examined in order to obtain a true $\delta^{13} \mathrm{C}$ record for the oceanic reservoir.

So far as the variation in $\delta^{13} \mathrm{C}$ content within the ocean at a particular time is concerned, one may consider (1) the distribution of $\delta^{13} \mathrm{C}$ in surface waters, and (2) the distribution in deep water. Regarding (1) the situation has only recently been explored in the modern ocean (Kroopnick et al., in press) and is quite complex. In a general sense both the oxygen isotopic composition of foraminiferal tests (reflecting the temperature of the water in which the tests were deposited) and the carbon isotopic composition of the tests (reflecting their position on the carbon isotopic profile in the water column) are indicators of the depth in the water column at which the bulk of calcification of a foraminiferal population has occurred. A decrease in temperature with depth is nearly universal in the oceans, and the order of planktonic foraminiferal depth stratification implied by isotopic measurements is in accord with other data (Emiliani, 1954).

On the other hand, the profile of $\delta^{13} \mathrm{C}$ with depth is not everywhere monotonic (Duplessy, 1972; Kroopnick, 1974), and carbon isotope values in foraminifera do not always yield a correct portrayal of their depth stratification (Shackleton and Vincent, 1975). Two complexities have been postulated. Firstly, certain Recent species (for example, Globigerina rubescens) appear to deposit their tests with both oxygen and carbon isotopic compositions light to equilibrium values (the so-called vital effect of Urey, 1947). Secondly, in an area in which $\delta^{13} \mathrm{C}$ is most negative in the water column at about the depth of the oxygen minimum, and rises (becomes more positive) below that, a similar trend in the $\delta^{13} \mathrm{C}$ should be reflected in the carbonate of the planktonic foraminiferal tests (Shackleton and Vincent, 1975).

Despite these complications, it is clear that in any part of the ocean in which photosynthetic activity does leave photic zone waters' dissolved $\mathrm{CO}^{2}$ with a positive $\delta^{13} \mathrm{C}$ value, the trend ought to be seen in the $\delta^{13} \mathrm{C}$ values in foraminiferal tests.

In deep waters the situation is more straightforward. Briefly, in the North Atlantic, deep water presently forms with a rather positive $\delta^{13} \mathrm{C}$ content (Kroopnick, 1974; Duplessy, 1972). As the deep water mass passes south in the Atlantic and ultimately north into the $\mathrm{Pa}$ cific, the dissolved carbon becomes progressively isotopically lighter as organic material falls, is oxidized, and contributes to the deep dissolved inorganic pool as the water mass proceeds along its path. Broecker $(1971,1974)$ has depicted this process in terms of nutrient cycling processes and the gradual depletion of nutrients, $\mathrm{O}$, and the change in deep-water $\mathrm{CO}_{3}$ - values between the deep waters at their source in the Atlantic and at their arrival in the North Pacific.

Unpublished analyses by Shackleton show that this trend of $\delta^{13} \mathrm{C}$-lightening may be charted in the $\delta^{13} \mathrm{C}$ content of Recent benthic foraminifera from the Atlantic to the Pacific oceans, although some regional anomalies also exist. A similar trend has been discerned in the $\delta^{13} \mathrm{C}$ content of deep-dwelling planktonic and benthic foraminifera of Oligocene age from Sites 366 and 357 in the equatorial and South Atlantic (Boersma and Shackleton, 1978).

\section{FORAMINIFERAL TAXONOMY AND BIOSTRATIGRAPHY}

Due to the continuing ambiguity concerning the taxonomy of Paleocene planktonic foraminifera, a conservative approach is adopted here. Chiloguembelina, Guembelitria, and Globoconusa are used in the sense of Loeblich et al. (1957) and Acarinina, in the sense of Subbotina (1953). Although it is not satisfactory, all 
keeled globorotaliid-form, spiny species and their assumed predecessors are included in the morozovellids (McGowran, 1968). The smooth-walled globorotaliidform species are included in Planorotalites, and the honeycomb-walled globigerinid-form species in $S u b$ botina. Despite the several species of Chiloguembelina identified in the Paleocene (Beckman, 1957), only one is used to encompass the whole group, $C$. midwayensis (Cushman). Generic assignments are given in Table 2.

It appears for the Eocene, and now for the Paleocene, that the depth habitat of a taxon, determined from its $\delta^{18} \mathrm{O}$ and $\delta^{13} \mathrm{C}$ stratification, may lend further evidence towards its taxonomic reassignment. This possibility is considered in another publication (Boersma, Premoli Silva, and Shackleton, in preparation).

The biostratigraphic zonation and time scale used in this paper are those of Berggren (1972). However, the lowest zones of his scheme were not applicable here due both to the fact that the "Globigerina" eugubina Zone has not been incorporated into his scheme, and to the fact that Subbotina triloculinoides does not appear first in Zone P.1 (thus defining the base of P.1b), but rather this species occurs as early as the " $G$." taurica Zone in the Pacific (Krasheninikov, 1971), and the basal "G." eugubina Zone (Boersma, 1977) on the São Paulo Plateau. Therefore, three zones were used for the basal Paleocene in the sense of Premoli Silva and Bolli (1973): The "G." eugubina Zone; the "Globorotalia" pseudobulloides Zone, corresponding to Berggren's P.1a, P.1b, and P.1c, and the "Globorotalia" trinidadensis Zone, corresponding to Berggren's P.1d. When possible, nannofossil zones have also been identified by various workers and friends.

TABLE 2

Generic Assignments of the Species Analyzed in This Paper ${ }^{\mathrm{a}}$

\begin{tabular}{|c|c|c|}
\hline Morozovella & Subbotina & Planorotalites \\
\hline trinidadensis & pseudobulloides & fringa \\
\hline inconstans & triloculinoides & eugubina \\
\hline uncinata & trilocularis & compressa \\
\hline $\begin{array}{l}\text { angulata } \\
\text { pusilla }\end{array}$ & & $\begin{array}{l}\text { ehrenbergi } \\
\text { pseudomenardii }\end{array}$ \\
\hline $\begin{array}{l}\text { conicotruncata } \\
\text { aequa }\end{array}$ & Acarinina & \\
\hline $\begin{array}{l}\text { velascoensis } \\
\text { occlusa }\end{array}$ & $\begin{array}{l}\text { primitiva } \\
\text { mckannai }\end{array}$ & Guembelitria \\
\hline $\begin{array}{l}\text { simulatis } \\
\text { pseudoscitula }\end{array}$ & $\begin{array}{l}\text { coalingensis } \\
\text { nitida }\end{array}$ & cretacea \\
\hline subbotinae & $\begin{array}{l}\text { pseudotopilensis } \\
\text { soldadoensis }\end{array}$ & Globoconusa \\
\hline Chiloguembelina & & daubjergensis \\
\hline midwayensis & & \\
\hline
\end{tabular}

${ }^{\mathrm{a}}$ Analyzed species are listed under the genera in which they are included in this paper according to the concepts of Loeblich et al. (1957), Subbotina (1953), and McGowran (1968). Species from the " $G$." eugubina Zone are named according to the taxonomy of Premoli Silva (in preparation).

\section{SITE 384}

\section{Introduction}

DSDP Leg 43, Site 384, was drilled on $J$-Anomaly Ridge where it emerges above the lower continental rise south of the Grand Banks, western North Atlantic. The site lies at $40^{\circ} 21^{\prime} \mathrm{N}, 51^{\circ} 39^{\prime} \mathrm{W}$ (Figure 1) presently in the part of the Gulf Stream where it diverges and merges with the laminar flow of the North Atlantic Drift. At a depth of 3909 meters, this site presently stands in the path of the North Atlantic Bottom Water as it winds its way from the Norwegian Sea around the Grand Banks, south into the equatorial regions, and subsequently into the South Atlantic.

The paleolatitude of this site during the Tertiary has not been determined; paleodepth estimates based on the back-tracking technique (Tucholke and Vogt, this volume) suggest this site stood at depths close to 3700 meters in the Paleocene.

\section{Sediment Descriptions and Preservation}

Cores 13 (Cretaceous) to 6 (top Paleocene) were included in this study. The Cretaceous/Tertiary boundary is located within a "transition zone" extending from Samples $13-3,32 \mathrm{~cm}$ to $13-3,53 \mathrm{~cm}$. Cretaceous sediment below the boundary is lighter in color than the Paleocene above, while the boundary itself is characterized by a mixed interval of lighter and darker chalky sediments. Some Cretaceous material is found in Paleocene levels as attested by its lighter color. Little deformation was recorded in the core.

Paleocene sediments are described (this volume) as nannofossil chalk, mottled in appearance, which becomes more indurated in younger cores. Induration is accompanied by increasing percentages of siliceous fossils and slightly decreasing calcium carbonate contents. In Cores 12 fossils are generally well preserved; some have adherent carbonate coatings. There are no siliceous fossils in the coarse fraction and benthic foraminifera are rare and small. Beginning in Core 11, Section 4 which encompasses both planktonic Zones P.2 and P.3 ( 58-61 m.y.) siliceous fossils become more abundant. Radiolaria are found in the lower section of this core, and in higher sections are accompanied by diatoms and abundant spicules. Benthic foraminifera are more common and larger in size than in the older sediments. Carbonate bomb measurements indicate carbonate percentages of approximately 80 per cent.

By Core 10 the siliceous component has increased and contains abundant spicules, as well as the other siliceous fossils; benthic foraminifera are again more rare than in the preceding core. In Core 10 and above sediments become more indurated, the siliceous component of the coarse fraction increases, and by Core 8 there is significant carbonate dissolution and loss of planktonic foraminifera. In Cores 7 and 6 the siliceous component comprises roughly 90 per cent of the coarse 
fraction. In levels where planktonic foraminiferal preservation is poor, the benthic foraminiferal content is greater. By Core 5 (Eocene) carbonate bomb values indicate only about 58 to 60 per cent calcium carbonate in the sediment.

\section{SITE 384 RESULTS}

\section{Surface Temperature Record}

The fluctuations in the near-surface temperature record for the Paleocene at Site 384 are shown in Figure 2; values used in this figure are listed in Table 3. All analyses were unispecific.
In order to construct a surface zone temperature curve, the warmest species in each of the early samples is plotted. As discussed later, our most recent analyses imply that Guembelitria cretacea produces the warmest temperatures of all early Paleocene species; however, it has not yet been possible to go back and analyze Guembelitria from Site 384 . However, by the time of Zone P.2, Morozovella uncinata registers surface temperature, and therefore, the surface temperature record is composed of isotopic analyses of the members of this lineage through the remainder of the Paleocene.

The warmest planktonic species in the older cores is Chiloguembelina midwayensis. This form gives a temperature of $14^{\circ} \mathrm{C}$ through Zone P.1 ( 65-61 m.y.);

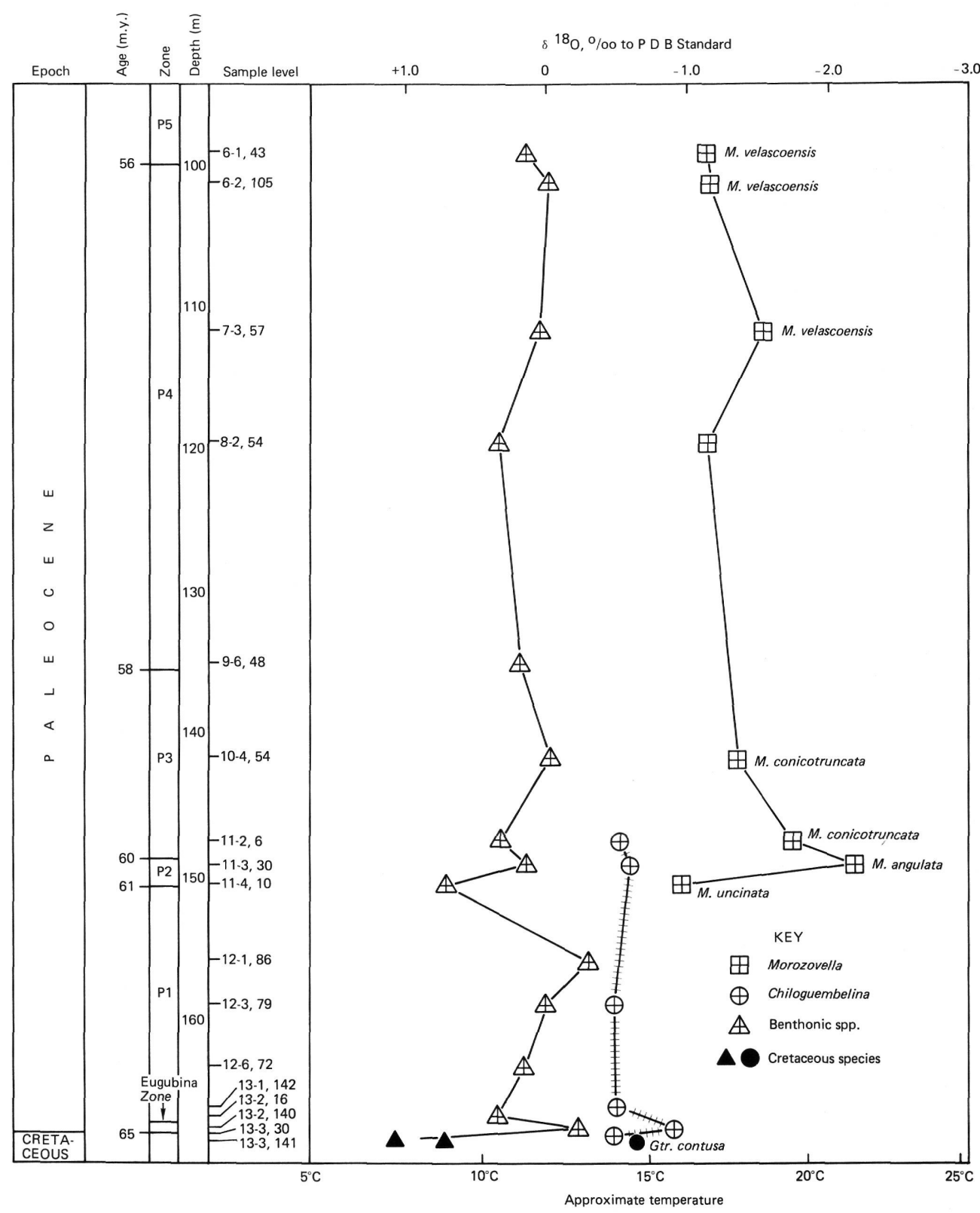

Figure 2. Paleotemperature record through the Paleocene at Site 384 in the western North Atlantic. All planktonic foraminiferal samples were unispecific; most benthic samples were not. We are not certain we are measuring surface temperature until Zone P.2 and also in the Cretaceous. 
TABLE 3

List of Site 384 Paleocene $\delta^{13} \mathrm{C}$ and $\delta{ }^{18} \mathrm{O}$ Values Arranged by Age

\begin{tabular}{|c|c|c|c|}
\hline $\begin{array}{c}\text { Sample } \\
\text { (Interval in } \mathrm{cm} \text { ) }\end{array}$ & Fossil & ${ }^{18} \mathrm{O}$ & ${ }^{1}{ }^{13} \mathrm{C}$ \\
\hline
\end{tabular}

\begin{tabular}{|c|c|c|c|}
\hline $13-2,143$ & $\begin{array}{l}\text { C. midwayensis } \\
\text { C. midwayensis } \\
P . \text { eugubina }+P \text {. fringa } \\
\text { Subbotina pseudobulloides } \\
\text { Mixed benthics }\end{array}$ & $\begin{array}{l}-0.97 \\
-0.88 \\
-0.70 \\
-0.60 \\
-0.24\end{array}$ & $\begin{array}{l}+0.48 \\
+0.60 \\
+1.04 \\
+1.59 \\
-0.00\end{array}$ \\
\hline \multicolumn{4}{|c|}{ Zone P.1 } \\
\hline $13-2,103$ & Whole sediment & -0.20 & +1.70 \\
\hline $13-2,16$ & Mixed benthics & +0.33 & +0.93 \\
\hline $13-1,142$ & $\begin{array}{l}\text { C. midwayensis } \\
\text { S. pseudobulloides }\end{array}$ & $\begin{array}{l}-0.52 \\
-0.47\end{array}$ & $\begin{array}{l}+1.38 \\
+1.40\end{array}$ \\
\hline $12-6,72$ & $\begin{array}{l}\text { S. pseudobulloides } \\
\text { Mixed benthics }\end{array}$ & $\begin{array}{l}-0.10 \\
+0.14\end{array}$ & $\begin{array}{l}+1.31 \\
+0.41\end{array}$ \\
\hline $12-3,79$ & $\begin{array}{l}\text { C. midwayensis } \\
\text { S. pseudobulloides } \\
\text { Mixed benthics }\end{array}$ & $\begin{array}{r}-0.50 \\
-0.45 \\
0.00\end{array}$ & $\begin{array}{l}+1.07 \\
+1.43 \\
+0.55\end{array}$ \\
\hline $12-1,81$ & $\begin{array}{l}\text { Planorotalites compressa } \\
\text { S. pseudobulloides } \\
\text { Subbotina triloculinoides } \\
\text { Mixed benthics }\end{array}$ & $\begin{array}{l}-0.49 \\
-0.28 \\
-0.22 \\
-0.32\end{array}$ & $\begin{array}{l}+0.95 \\
+1.35 \\
+1.34 \\
+0.16\end{array}$ \\
\hline \multicolumn{4}{|c|}{ Zone P.2 } \\
\hline $11-4,10$ & $\begin{array}{l}\text { Morozovella uncinata } \\
\text { P. compressa } \\
\text { S. pseudobulloides } \\
\text { S. triloculinoides } \\
\text { Mixed benthics }\end{array}$ & $\begin{array}{l}-0.98 \\
-0.41 \\
-0.31 \\
-0.25 \\
+0.70\end{array}$ & $\begin{array}{l}+2.29 \\
+1.45 \\
+1.58 \\
+1.58 \\
+0.44\end{array}$ \\
\hline $11-3,30$ & $\begin{array}{l}\text { M. angulata } \\
\text { M. pusilla } \\
\text { P. compressa } \\
\text { S. pseudobulloides } \\
\text { S. triloculinoides } \\
\text { C. midwayensis } \\
\text { C. midwayensis } \\
\text { Mixed benthics }\end{array}$ & $\begin{array}{l}-2.22 \\
-1.42 \\
-1.03^{\mathrm{a}} \\
-0.52 \\
+0.03 \\
-0.23 \\
-0.61 \\
+0.12\end{array}$ & $\begin{array}{l}+2.29 \\
+2.74 \\
+0.81^{\mathrm{a}} \\
+1.44 \\
+1.68 \\
+1.09 \\
+1.06 \\
-0.17\end{array}$ \\
\hline $11-2,6$ & $\begin{array}{l}\text { M. conicotruncata } \\
\text { M. pusilla } \\
\text { S. pseudobulloides } \\
\text { P. compressa } \\
\text { P. compressa } \\
\text { C. midwayensis } \\
\text { S. triloculinoides } \\
\text { Nuttalides } \\
\text { Bulimina } \\
\text { Mixed benthics }\end{array}$ & $\begin{array}{l}-1.78 \\
-1.11 \\
-0.81 \\
-0.69 \\
-0.47 \\
-0.54 \\
-0.45 \\
+0.09 \\
+0.63 \\
+0.31\end{array}$ & $\begin{array}{l}+2.52 \\
+1.54 \\
+0.64 \\
+0.85 \\
+0.63 \\
+0.60 \\
+0.92 \\
+0.46 \\
+0.20 \\
+0.24\end{array}$ \\
\hline $10-4,54$ & $\begin{array}{l}\text { M. conicotruncata } \\
\text { Planorotalites ehrenbergi } \\
\text { S. triloculinoides } \\
\text { S. pseudobulloides }\end{array}$ & $\begin{array}{l}-1.38 \\
-0.49 \\
-0.39 \\
-0.18\end{array}$ & $\begin{array}{l}+2.50 \\
+1.35 \\
+1.56 \\
+1.55\end{array}$ \\
\hline \multicolumn{4}{|c|}{ Zone P.4 } \\
\hline $9-6,48$ & $\begin{array}{l}\text { Planorotalites pseudoscitula } \\
\text { Planorotalites pseudomenardii } \\
\text { S. pseudobulloides } \\
\text { Mixed benthics }\end{array}$ & $\begin{array}{l}-0.73 \\
-0.40 \\
-0.41 \\
+0.18\end{array}$ & $\begin{array}{l}+2.65 \\
+1.81 \\
+1.99 \\
+0.76\end{array}$ \\
\hline $8-2,54$ & $\begin{array}{l}\text { M. conicotruncata } \\
\text { P. pseudomenardii } \\
\text { S. triloculinoides } \\
\text { Mixed benthics }\end{array}$ & $\begin{array}{l}-1.17 \\
-0.31 \\
-0.14 \\
+0.33\end{array}$ & $\begin{array}{l}+2.61 \\
+1.91 \\
+2.22 \\
+0.03\end{array}$ \\
\hline
\end{tabular}

TABLE 3 - Continued

\begin{tabular}{ccrc}
\hline $\begin{array}{c}\text { Sample } \\
(\text { Interval in cm) }\end{array}$ & Fossil & $\delta^{180}$ & $\delta^{13} \mathrm{C}$ \\
\hline \multirow{2}{*}{$7-3,57$} & M. velascoensis & -1.55 & +4.27 \\
& Mixed benthics & +0.04 & +1.11 \\
\multirow{2}{*}{$6-2,105$} & M. velascoensis & -1.18 & +4.23 \\
& Mixed benthics & 0.02 & +1.68 \\
\hline
\end{tabular}

Note: All carbon and oxygen values acquired to date. None of the benthic values are corrected for their deviation from $\delta 18 \mathrm{O}$ equilibrium; all benthic values not of mixed species are unispecific analyses.

andicates doubtful analysis results.

one lower value early in the G. pseudobulloides Zone suggests that there may have been a slight temperature drop at this time. The temperature remains close to $14^{\circ}$ in Zone P.2, but there is a substantial rise assumed to be in the surface zone temperatures to close to $21^{\circ} \mathrm{C}$ by Zone P.3, registered in the newly evolved species, Morozovella angulata. The presence of this foraminifer in abundance has been recorded in Laborador by Premoli Silva (written communication, 1977) corroborating that there is, in fact, a real rise in surface temperatures at this time.

While warmer temperatures characterize the early part of Zone P.3, cooler temperatures return later in P.3 ( $\sim 59$ m.y.) and continue throughout the later Paleocene; the average temperature at this time is close to $18^{\circ} \mathrm{C}$. The temperature does not rise again until later in the early Eocene.

\section{Surface Zone Carbon Isotopic Record}

The record of $\delta^{13} \mathrm{C}$ through the Paleocene at Site 384 is shown in Figure 3 (again uncertainty exists as to the habitat of early Paleocene planktonics). This record shows some fluctuations, but a late Paleocene (Zone P.4, 56-58 m.y.) major carbon isotope excursion is recorded in the near-surface morozovellids. This excursion (in the positive direction) is paralleled by an overall increase in the spread of carbon isotopic values through the upper water column and from the surface to the bottom (see Figure 4). It apparently occurs in the latter part of Zone P.4, the interval corresponding to nannofossil Zone NP 8, around 57-56 m .y. The possible significance of this excursion is discussed later (see Discussion).

\section{Bottom Temperature Record}

The bottom temperature record through the Paleocene at Site 384 is shown in Figure 2. It was rarely possible to make unispecific analyses at this site; therefore, where possible, benthics whose departure from equilibrium is known were grouped together. Although these bottom temperatures are only approximate, we do know that most species analyzed are a little isotopically light to equilibrium values (Boersma and Shackleton, $1977,1978)$ so that the measured temperatures are probably slightly higher than the true bottom temperatures at this site.

The most noteworthy feature of this temperature pattern is the low amplitude of the fluctuations. Other 


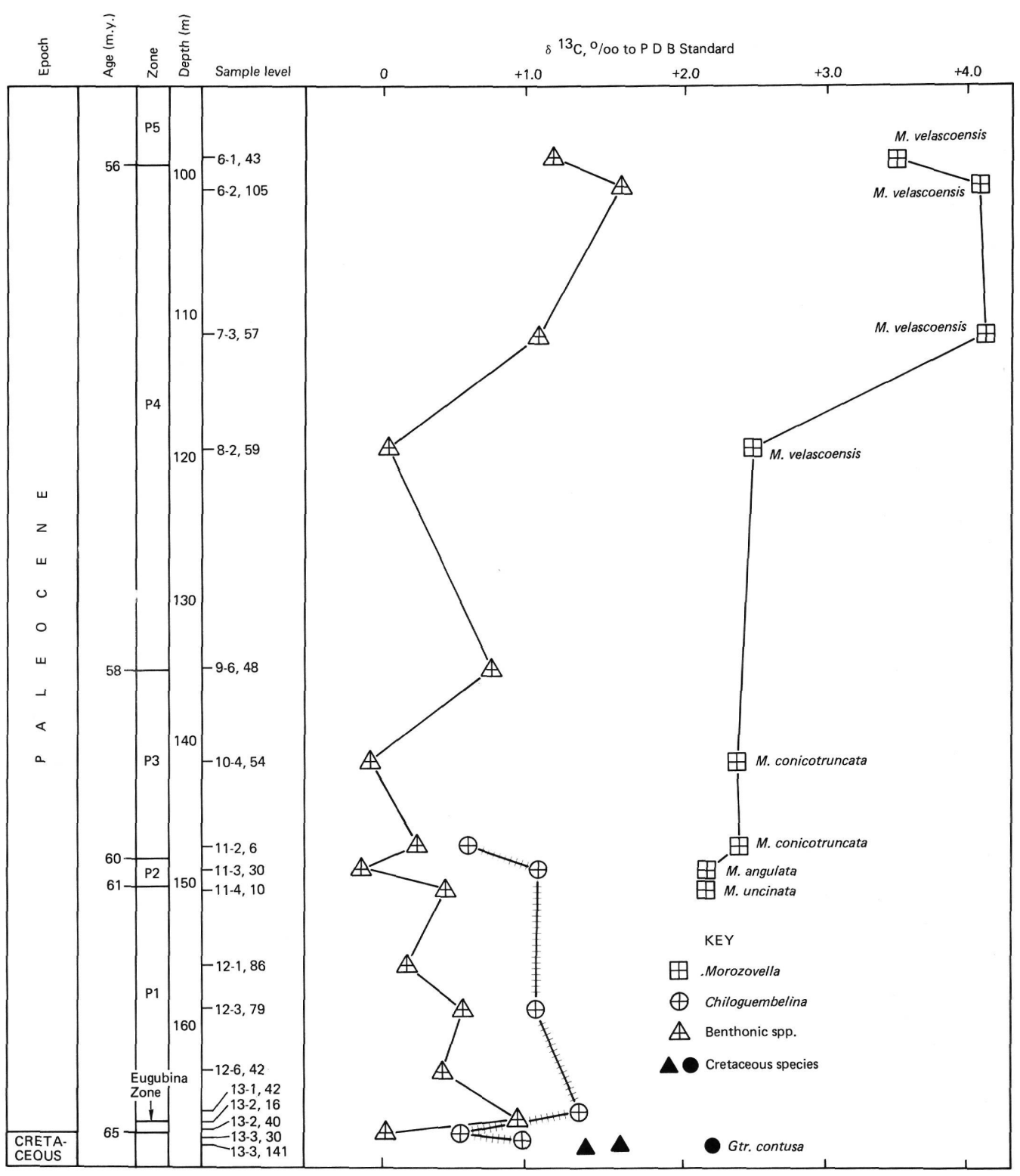

Figure 3. Carbon isotopic record through the Paleocene at Site 384 based on benthic and planktonic foraminiferal measurements on the same samples shown in Figure 2. The carbon excursion is much less pronounced here than in equatorial sites.

bottom temperature analyses discussed later show a similar lack of temperature fluctuations during this time period. However, the changes that do occur roughly parallel the temperature changes in the planktonic foraminiferal record, suggesting that the temperature changes are in phase, at least at this level of refinement.

Relative to the Cretaceous before and the Eocene following, the intermediate depth bottom temperatures at Site 384 vary little, ranging from a low of $8.5^{\circ} \mathrm{C}$ in Zone P.2 to a high of $13.5^{\circ} \mathrm{C}$ in the top of Zone P.1. Little fluctuation occurs in the bottom temperature at this site after the middle Paleocene (Zone P.3) and across the Paleocene/Eocene boundary. At the other sites analyzed, the same pattern emerges. It is also noteworthy that bottom temperatures in the basal $\mathrm{Pa}$ - leocene are markedly warmer than those at equivalent depths in the latest Cretaceous, and that the rise in temperature was rapid.

\section{Carbon Isotopic Record on the Bottom}

Relative to the surface carbon record at Site 384 , there is even less change in the carbon values for the benthic foraminifera (Figure 3 ). Unfortunately, the carbon measurements on mixed benthic species may be even more variable than the oxygen measurements, as benthics apparently demonstrate even greater departures from carbon isotopic equilibrium than from oxygen isotopic equilibrium (Shackleton, unpublished data). However, the parallelism between values from the deeper-dwelling planktonic foraminifera and parts of the $\delta^{13} \mathrm{C}$ curve suggests that in those samples the 


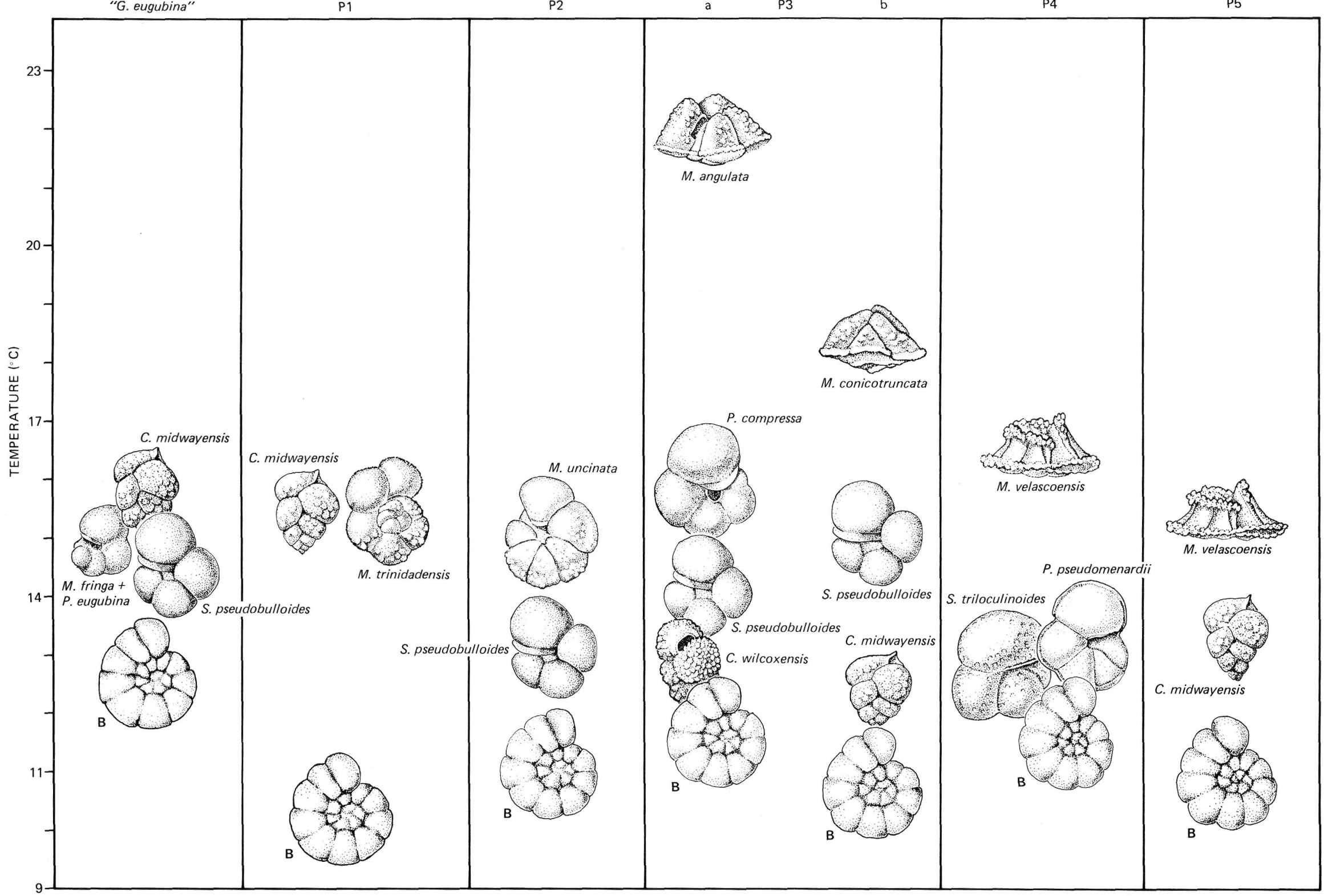

Figure 4. Temperature stratification of selected planktonic foraminifera plotted relative to benthic foraminiferal measurements for samples from Site 384. Benthics are marked with a $B$. Notice the warming in Zone P.3, which accentuates the vertical spread among the foraminiferal species. By this time the foraminifera are separated into a warmer and a distinctly cooler grouping of species; the cooler group of species also occupies levels with lower oxygen contents (more negative carbon isotope values.) 
benthic values may be reflecting changes in the bottom $\mathrm{C}$ ratios rather than just changes in the specific composition of the sample analyzed.

\section{PLANKTONIC FORAMINIFERAL DEPTH STRATIFICATION}

The stratification order of planktonic foraminiferal species and the temperatures at which each lived can be estimated from the oxygen isotopic composition of their test carbonate (on the assumption that warmer temperatures occur nearest the surface of the ocean and that each species is precipitating its test in isotopic equilibrium with the surrounding water mass). As discussed earlier, the former assumption is essentially universally true; as there exists no way to test the equilibrium assumption for extinct species, we choose to assume equilibrium fractionation until evidence shows otherwise. To obviate other problems, such as summer/winter differences in isotopic composition, or the differences between adults and juveniles, we consistently analyze more than nine adults of each species studied.

Suites of Paleocene planktonic foraminiferal species, predominantly from Sites 384, 86, and 95 in the North Atlantic and Gulf of Mexico, and 356, 20C, and 144A in the South Atlantic, were measured from each zone of the Paleocene and from the tops and bottoms of longer zones. The results of many of these analyses are given in Table 4 and shown diagramatically for Sites 384 and 356 in Figures 4 and 5.

It has heretofore been assumed that throughout the Tertiary planktonic foraminifera have been stratified in the same relative order as their Recent "counterparts." By this reasoning keeled globorotaliid-form species in the Recent should be analogous with the keeled globorotaliid-form species (morozovellids, planorotalids) of the early Tertiary; and globigerinid-form species should be analogous with the subbotinids and globigerinids of the Paleogene. The order of species lacking Recent counterparts has obviously not been considered in this assumption. Further, similar morphologies of several planktonic foraminiferal groups which have evolved iteratively during the Cretaceous and Tertiary have been considered analogous (Frerichs, 1971), both in the order in which they would stratify (Douglas and Savin, 1973) as well as to the possible function of their morphologies at those relative depths (Hecht and Savin, 1971) primarily in terms of their relationship to temperature and water density (Marzalek, personal communication, 1975). Similar morphologic features (for example, the keel), then, are considered as analogous adaptations to similar environmental variables (for example, cooler temperatures or higher densities) whenever they appear.

For the Recent Shackleton and Vincent (1975) discovered the following relevant facts:

1) even Recent species do not always stratify in analogous order. In warmer sites Globorotalia menardii lives below Neogloboquadrina deutertrei, Pulleniatina obliquiloculata, Orbulina universa, and Globigerinella
TABLE 4

List of Paleocene $\delta{ }^{13} \mathrm{C}$ and $\delta{ }^{18} \mathrm{O}$ Values Arranged by Age

\begin{tabular}{|c|c|c|c|}
\hline $\begin{array}{c}\text { Sample } \\
(\text { Interval in } \mathrm{cm}) \\
\end{array}$ & Fossil & $\delta^{18} \mathrm{O}$ & $\delta^{13 \mathrm{C}}$ \\
\hline \multicolumn{4}{|c|}{$\begin{array}{c}\text { "Globigerina" eugubina } \\
\text { Zone }\end{array}$} \\
\hline \multirow[t]{3}{*}{$356-29-3,33$} & $\begin{array}{l}\text { Guembelitria cretacea } \\
\text { Chiloguembelina midwayensis } \\
\text { Planorotalites eugubina and }\end{array}$ & $\begin{array}{l}-2.49 \\
-1.78\end{array}$ & $\begin{array}{l}+0.21 \\
+0.80\end{array}$ \\
\hline & P. fringa & -1.36 & +1.50 \\
\hline & Mixed benthics & +0.13 & +1.28 \\
\hline \multirow[t]{5}{*}{$384-13-2,143$} & C. midwayensis & -0.97 & +0.48 \\
\hline & C. midwayensis & -0.88 & +0.60 \\
\hline & $P$. eugubina $+P$. fringa & -0.70 & +1.04 \\
\hline & Subbotina pseudobulloides & -0.60 & +1.59 \\
\hline & Mixed benthics & -0.24 & -0.00 \\
\hline $356-29-3,30$ & C. midwayensis & -1.56 & +1.02 \\
\hline \multirow[t]{2}{*}{$356-29-3,24$} & C. midwayensis & -1.98 & +0.77 \\
\hline & S. pseudobulloides & -1.47 & +1.60 \\
\hline \multicolumn{4}{|c|}{ Zone P.1 } \\
\hline $384-13-2,103$ & Whole sediment & -0.20 & +1.70 \\
\hline $384-13-2,16$ & Mixed benthics & +0.33 & +0.93 \\
\hline \multirow[t]{2}{*}{$384-13-1,142$} & C. midwayensis & -0.52 & +1.38 \\
\hline & S. pseudobulloides & -0.47 & +1.40 \\
\hline \multirow[t]{2}{*}{$384-12-6,72$} & S. pseudobulloides & -0.10 & +1.31 \\
\hline & Mixed benthics & +0.14 & +0.41 \\
\hline \multirow[t]{3}{*}{$384-12-3,79$} & C. midwayensis & -0.50 & +1.07 \\
\hline & S. pseudobulloides & -0.45 & +1.43 \\
\hline & Mixed benthics & 0.00 & +0.55 \\
\hline \multirow[t]{3}{*}{$384-12-1,81$} & Planorotalites compressa & -0.49 & $\begin{array}{l}+0.95 \\
+1.35\end{array}$ \\
\hline & $\begin{array}{l}\text { S. pseudobulloides } \\
\text { Subboting triloculinoides }\end{array}$ & -0.28 & $\begin{array}{l}+1.35 \\
+1.34\end{array}$ \\
\hline & $\begin{array}{l}\text { Subbotina triloculinoides } \\
\text { Mixed benthics }\end{array}$ & $\begin{array}{l}-0.22 \\
-0.32\end{array}$ & $\begin{array}{l}+1.34 \\
+0.16\end{array}$ \\
\hline \multirow[t]{2}{*}{$356-29-2,108$} & G. cretacea & -1.48 & +0.20 \\
\hline & S. pseudobulloides & -1.13 & +1.45 \\
\hline \multirow[t]{6}{*}{$356-29-2,80$} & G. cretacea & -2.09 & +0.12 \\
\hline & Globoconusa daubjergensis & -1.95 & +0.32 \\
\hline & G. daubjergensis & -1.81 & +0.30 \\
\hline & S. pseudobulloides & -1.43 & +1.76 \\
\hline & C. midwayensis & -1.40 & +0.50 \\
\hline & Nuttalides & +0.06 & +1.94 \\
\hline $356-29-1,92$ & Mixed benthics & +0.28 & +1.03 \\
\hline \multirow[t]{3}{*}{$356-29-1,50$} & Morozovella aff. trinidadensis & -2.07 & +0.90 \\
\hline & C. midwayensis & -1.79 & -0.11 \\
\hline & S. pseudobulloides & -1.60 & +0.87 \\
\hline $356-29-1,20$ & C. midwayensis & -1.80 & +0.06 \\
\hline $356-28-6,62$ & Mixed benthics & -0.02 & +0.64 \\
\hline $356-27-2,30$ & Mixed benthics & -0.18 & +0.14 \\
\hline \multirow[t]{6}{*}{$356-26-6,80$} & G. cretacea & -2.90 & +0.11 \\
\hline & P. compressa & -2.26 & +0.64 \\
\hline & M. trinidadensis & -2.17 & +1.13 \\
\hline & S. pseudobulloides & -1.87 & +0.95 \\
\hline & Nuttalides + Gavelinella & -1.06 & +0.80 \\
\hline & Mixed benthics & -1.02 & +0.63 \\
\hline
\end{tabular}


TABLE 4 - Continued

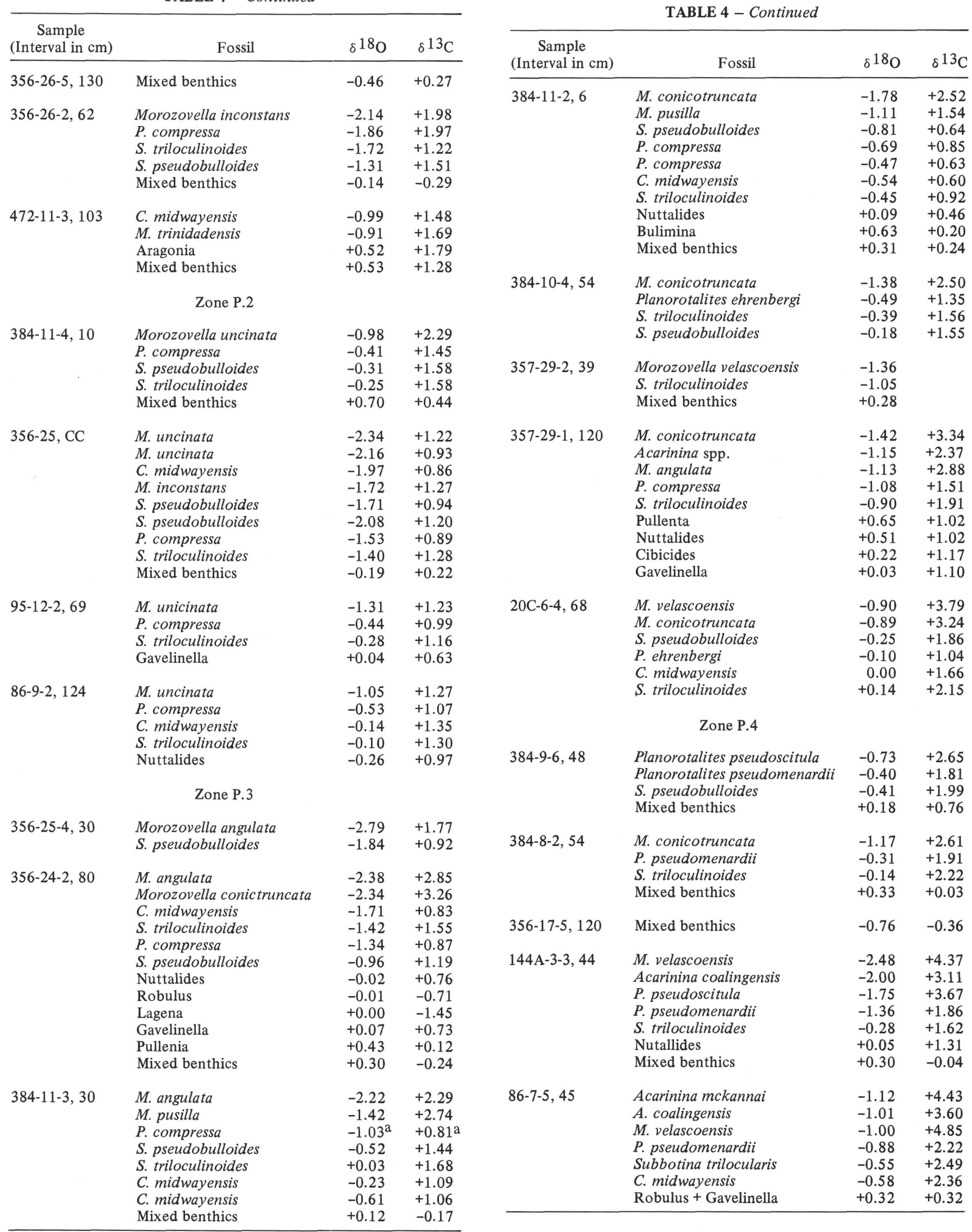


TABLE 4 - Continued

\begin{tabular}{|c|c|c|c|}
\hline $\begin{array}{c}\text { Sample } \\
\text { (Interval in } \mathrm{cm} \text { ) }\end{array}$ & Fossil & ${ }^{18}{ }^{18}$ & ${ }^{13} \mathrm{C}$ \\
\hline \multirow[t]{3}{*}{$86-7-2,75$} & M. velascoensis & -1.26 & +4.71 \\
\hline & C. midwayensis & -0.50 & +2.22 \\
\hline & S. trilocularis & -0.53 & +2.38 \\
\hline \multirow[t]{3}{*}{$384-7-3,57$} & M. velascoensis & -1.55 & +4.27 \\
\hline & Mixed benthics & +0.04 & +1.11 \\
\hline & Zones P.5-P.6 & & \\
\hline \multirow[t]{2}{*}{$384-6-2,105$} & M. velascoensis & -1.18 & +4.23 \\
\hline & Mixed benthics & 0.02 & +1.68 \\
\hline \multirow[t]{2}{*}{$384-6-1,43$} & M. velascoensis & -1.14 & +3.65 \\
\hline & Mixed benthics & +0.14 & +1.20 \\
\hline \multirow[t]{8}{*}{$20 \mathrm{C}-6-3,55$} & A. mckannai & -0.92 & +3.37 \\
\hline & A. coalingensis & -0.85 & +3.40 \\
\hline & Morozovella aequa & -0.83 & +3.97 \\
\hline & S. trilocularis & 0.00 & +2.09 \\
\hline & Gavelinella & +0.17 & -1.47 \\
\hline & Nuttalides & +0.36 & +1.27 \\
\hline & Aragonia & $+1.19^{a}$ & $+0.50^{\mathrm{a}}$ \\
\hline & Cibicides & +0.09 & +1.68 \\
\hline \multirow[t]{7}{*}{$20 \mathrm{C}-6-3,30$} & A. coalingensis & -0.90 & +3.62 \\
\hline & M. aequa & -0.72 & +3.87 \\
\hline & Mixed acarininids & -0.66 & +3.32 \\
\hline & tiny globorataliid & -0.59 & +1.62 \\
\hline & M. velascoensis & -0.42 & +3.47 \\
\hline & S. trilocularis & -0.18 & +2.10 \\
\hline & Gavelinella & -0.06 & +1.41 \\
\hline \multirow[t]{7}{*}{$20 \mathrm{C}-6-2,40$} & M. velascoensis & -1.14 & +3.79 \\
\hline & Morozovella subbotinae & -0.73 & +3.76 \\
\hline & M. aequa & -0.65 & +3.88 \\
\hline & $S$. trilocularis & -0.23 & +2.18 \\
\hline & Nuttalides & +0.17 & +1.24 \\
\hline & Bulimina & +0.12 & +0.88 \\
\hline & Anomalina & -0.03 & +1.54 \\
\hline \multirow[t]{6}{*}{$21-2-1,100$} & Acarinina nitida & -0.88 & +2.27 \\
\hline & M. subbotinae & -0.82 & +3.14 \\
\hline & A. coalingensis & -0.77 & +2.28 \\
\hline & S. trilocularis & -0.23 & +1.32 \\
\hline & C. midwayensis & -0.08 & +0.89 \\
\hline & Nuttalides & +0.04 & +0.63 \\
\hline \multirow[t]{2}{*}{$94-33-1,40$} & M. subbotinae & -1.55 & +2.85 \\
\hline & Mixed benthics & -0.17 & +0.55 \\
\hline \multirow[t]{2}{*}{$94-33-2,79$} & A. nitida & -1.56 & +2.35 \\
\hline & M. subbotinae & -1.43 & +2.61 \\
\hline
\end{tabular}

Note: All carbon and oxygen values acquired to date. None of the benthic values are corrected for their deviation from $\delta 180$ equilibrium; all benthic values not of mixed species are unispecific analyses.

andicates doubtful analysis results.

siphonifera; in cooler waters, these same species stratify below G. menardii.

2 ) in the Recent the globigerinid-form species Globigerina rubescens, Globigerinoides ruber, G. conglobatus, and G. sacculifer together with the bullate Globigerinita glutinata occur at the surface.

3) an intermediate group consists of species of Pulleniatina, Sphaeroidinella, Orbulina, and Globigerinella, and Neogloboquadrina; in most cases the species of Globorotalia calcify in the deepest waters; the flatter $G$. menardii above the high, acute-umbilicate $G$. truncatulinoides, above the smooth $G$. scitula.

Even a general comparison of this grouping with the three early Cenozoic groups demonstrates that the stratification order is not analogous. In the Recent globigerinid-form species dominate surface water; in the early Paleogene globorataliid-form species dominate surface water relative to the globigerinid-form species. Although $G$. menardii and $P$. pseudomenardii may be considered roughly comparable in that they occupy intermediate depth waters, $P$. pseudomenardii is consistently underlain by globigerinid-form species and overlain by the keeled globorotaliid-form morozovellids. This simple analysis points out that our assumptions about analogues need to be reconsidered in terms of a realization that the beginning of the Cenozoic was not entirely analogous with the end of it.

Consideration of the suites of species shown in Figures 4 and 5 and Tables 3 and 4 can help clarify some of our ideas on planktonic foraminiferal depth stratification. In order to visualize most clearly the order of planktonic foraminifera in the water column, it is easiest to examine samples from the equatorial regions (or, during warmest times at middle latitudes) where there is a wider range of temperatures through which the foraminifera apparently spread out (Shackleton and Vincent, 1975; Boersma and Shackleton, 1978). Thus the generalized stratification orders shown in Table 5 are derived from low-latitude samples where possible, and augmented with mid-latitude samples when necessary. Comparison of the data in this table and the multitude of values listed in Table 4 demonstrates that there are several inversions of values. These may be due to the possibility of mixing, increased in any core catcher sample, to the range of ages present in any $2-\mathrm{cm}$ sample and hence to the range of temperatures represented, and/or to the close spacing between some species. To construct the generalized stratification scheme we attempted to weigh all these possibilities by considering as many samples as possible, and by consideration of the carbon values.

In samples from the equatorial region where the widest range of temperatures is encountered and hence the widest vertical spread of the foraminifera, it is possible to divide the planktonics into three main groups along the temperature gradient: those which typify the warmest waters, considered the species of the photic zone; the warm group which inhabits warm waters, also in the photic zone; and the cooler group, which occupies the cooler waters and probably extending to intermediate depths in some cases down to and below the depth of the oxygen-minimum zone and the thermocline layer (considered here as the interval over which there is the greatest rate of change in temperature values). If these groups are considered to inhabit parcels of water, then their biogeography can be considered as reflecting the geographic distributions of water masses. 


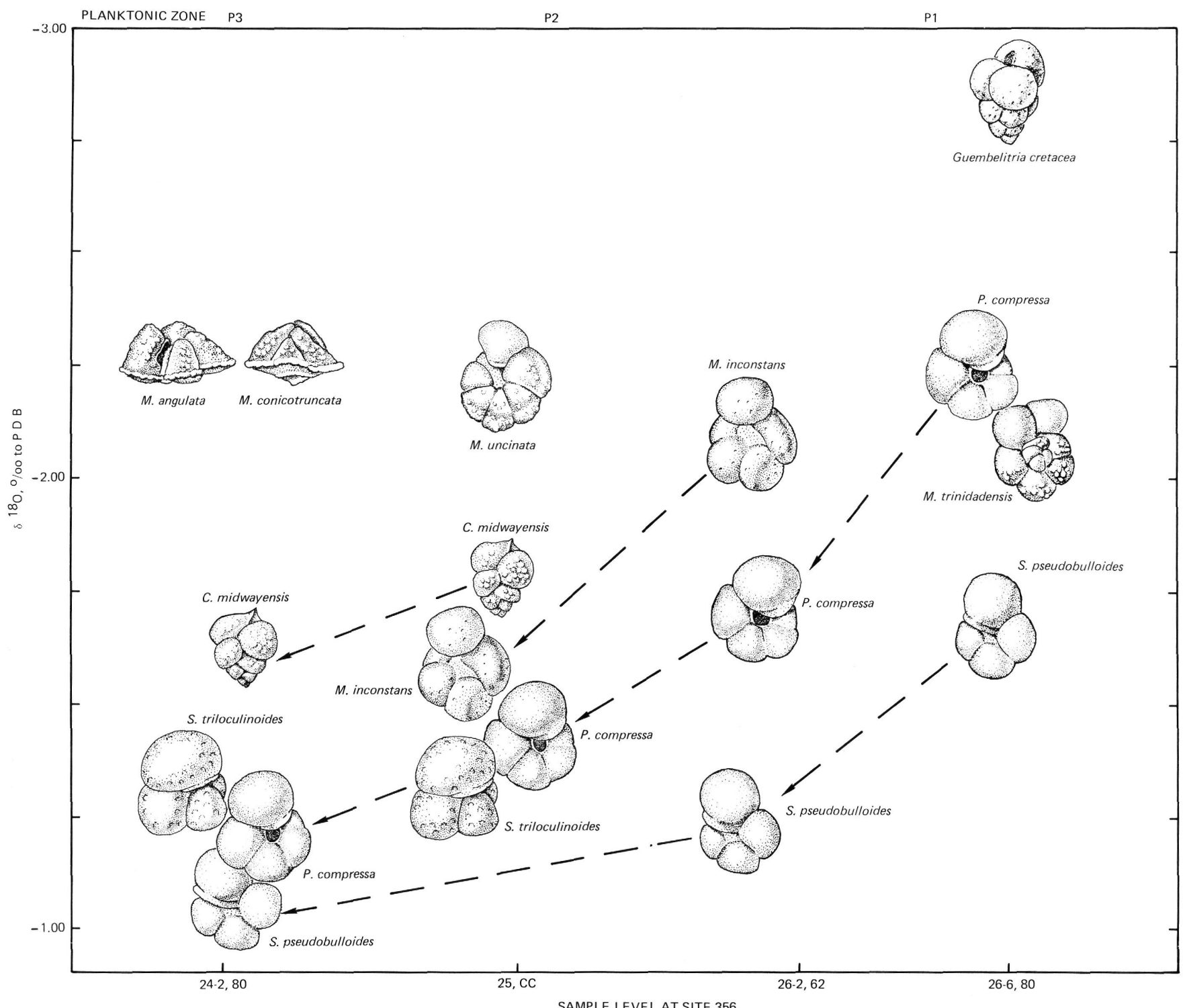

Figure 5. Planktonic foraminiferal depth stratification through the early and mid Paleocene at Site 356 in the middle latitude South Atlantic. This site always registers significantly warmer temperatures than Site 384 or the Gulf of Mexico sites, 86 and 95 which demonstrates the continuity of warm surface water deriving from the equatorial and low latitude Tethyan extension flowing south along the margin of South America to slightly greater than $30^{\circ}$ south. At the nearby Site 357, however, significantly cooler temperatures suggest a southern source for a northward-flowing cool current which, in the Eocene, brings a significant proportion of high latitude species to nearby Site 357, but not Site 356. After the temperature maximum in Zone P.1, registered by Guembelitria, the temperature stabilized at a lower average around $21^{\circ} \mathrm{C}$. Concomitant with these cooler temperatures as well as the temperature rise at the base of Zone P.3, was the progressive descent of the low oxygen species to cooler and cooler temperatures. 
TABLE 5

Generalized Depth Stratification Order of Paleocene Planktonic Foraminiferal Genera

\begin{tabular}{|c|c|c|c|c|}
\hline $\begin{array}{c}\text { “G." eugubina } \\
\text { Zone }\end{array}$ & $\begin{array}{c}\text { Early } \\
\text { Zone P.1 }\end{array}$ & $\begin{array}{c}\text { Latest } \\
\text { Zone P.1 }\end{array}$ & Zone P.2 & Zones P.3-P.5 \\
\hline $\begin{array}{l}\text { Guembelitria } \\
\text { Chiloguembelina } \\
\text { Planorotalites } \\
\text { Subbotina }\end{array}$ & $\begin{array}{l}\text { Guembelitria } \\
\text { Globoconusa } \\
\text { Chiloguembelina } \\
\text { Planorotalites } \\
\text { Morozovella } \\
\text { Subbotina }\end{array}$ & $\begin{array}{l}\text { Globoconusa } \\
\text { Morozovella } \\
\text { Chiloguembelina } \\
\text { Planorotalites } \\
\text { Subbotina }\end{array}$ & $\begin{array}{l}\text { Morozovella } \\
\text { Chiloguembelina } \\
\text { Planorotalites } \\
\text { Subbotina }\end{array}$ & $\begin{array}{l}\text { Acarinina } \\
\text { Morozovella } \\
\text { Chiloguembelina } \\
\text { Planorotalites } \\
\text { Subbotina }\end{array}$ \\
\hline
\end{tabular}

Note: Each genus includes all measured species. Note the shift between early and latest P.1 in the relative position of Morozovella.

Figure 4, showing the depth stratification of planktonic foraminifera at Site 384 , best illustrates this division of forms into groupings. As the temperature increased in Zone P.3, the gap between the warm group of the now-keeled morozovellids and the globigerinid-form Subbotina triloculinoides and associated species widened. This cooler group is further distinguished from the warm species by the fact that although it occurred at a variety of relatively cool temperatures, the species $S$. triloculinoides and $S$. pseudobulloides lived within a very small range of carbon isotope values. This implies that the waters they inhabited were either of uniform carbon isotopic composition through the early and middle Paleocene, or that these forms changed their depth habitats to remain within a constant interval of ${ }^{13} \mathrm{C}$ values (probably reflecting some other variable such as oxygen, phosphorous, or biotic content).

Chiloguembelina, a constant constituent of this cooler water group, demonstrates wider fluctuations in its carbon isotope values. However different its carbon values, they are generally the most negative of all the foraminiferal values in a sample. This may indicate that Chiloguembelina is inhabiting that interval of the thermocline layer typified by lowest oxygen values (the oxygen minimum) during this part of the Tertiary. This association of light ${ }^{13} \mathrm{C}$ values with the level of the oxygen minimum has also been found in Recent foraminiferal species (Shackleton and Vincent, 1975).

Estimated temperatures at Site 356 are consistently warmer than those at Site 384, and thus allow more easily a visualization of the process occurring among the planktonic foraminifera (Figure 5). In the G. trinidadensis Zone, G. cretacea continued to inhabit the warmest waters, $M$. trinidadensis and $P$. compressa cluster at warm temperatures, while $S$. pseudobulloides and $S$. triloculinoides inhabited cooler temperatures. By the top of the $G$. trinidadensis Zone, $M$. inconstans inhabited warmer temperatures than $P$. compressa. In Zones P.2 and P.3, P. compressa descended to progressively cooler temperatures (and waters of very negative $\delta^{13} \mathrm{C}$ ) until in Zone P.3 it eventually evolved into the flatter, sometimes squarish $P$. ehrenbergi, with its subacute periphery. A similar trend of descending to cooler temperatures (and waters of more negative $\delta^{13} \mathrm{C}$ ) as the surface is apparently warming, and/or warmer forms are appearing at middle latitudes, is shown by the other cool water species. This small diagram very graphically demonstrates the change in depth habitat, the increase in parceling of the planktonic foraminifera, and the temperature relations in the bioseries $M$. inconstans-M. uncinata-M. angulata. The relative habitat of Chiloguembelina, so far as it has been analyzed, changes during the Paleocene, as this genus apparently stratifies in different order at different times.

Several other features of temperature stratification emerge from these data. When morphotypes of keeled morozovellids with closed umbilici were analyzed as compared with the same species with open umbilici, the open-umbilicate species registered higher temperatures. Similarly, when a keel is developed on a morozovellid from an unkeeled ancestral form, the keeled species registers lower temperatures. However, when the keel evolved on Planorotalities pseudomenardii from its predecessor, $P$. ehrenbergi, it occurred at nearly identical 180 values. In analyses of Eocene species, it has been demonstrated also that juvenile specimens of Globigerinatheka register higher temperatures than adults in the same sample.

\section{Water Mass Parcels and Foraminiferal Morphologies}

A cogent explanation for the distributions of planktonic foraminifera through the early Tertiary was given by Cifelli (1969) in a classic paper on planktonic foraminiferal evolution. Cifelli noticed that the planktonic foraminiferal faunas of the Oligocene, particularly in the later part, bore a close resemblance in overall aspect and in the morphologies present, to those of the Danian (equivalent to planktonic Zones P.1, "G." eugubina, and P.2). He characterized these faunas by their simplicity, by the shapes of morphotypes present, and by their distribution patterns. He then suggested that the water column could be envisioned as consisting of two parcels, a colder water and a warmer water parcel. The cold parcel contained globigerine species with a generalized shape, and the warmer one, all other morphotypes. A tendency towards mutual exclusion is maintained by the thermal gradients which prevent large-scale mixing between the water masses (parcels) involved. Thus, times of sharp thermal gradients are times of marked faunal boundaries and 
stricter barriers between water masses. Where there is a less intense thermal gradient, faunal boundaries are less distinct.

The parceling of niches, e.g., the diversity within a water mass, is partially maintained by seasonal succession. And reduced diversity may occur when thermal barriers are reduced, water bodies lose their identities, and only the morphotypes associated with that parcel occur. The times of uniformly "cool"l waters, such as the Danian and the Oligocene, exemplify this idea. He concludes, and this is significant for us who try to imagine conditions not strictly analogous to today's, that it is difficult to imagine surface waters without strong latitudinal differentiation of faunas. Nevertheless, it is unlikely that Danian or Oligocene faunas could have been supported under conditions like those that prevail today.

While it is possible to enlarge upon the parceling and subparceling of water masses, Cifelli's conceptualization provides a good explanation for the vertical distribution of planktonic foraminiferal faunas of the $\mathrm{Pa}$ leocene. When two very different parcels, warm and cool, which could be considered water masses, are present, diversity increases; thermal gradients are strongest, barriers to vertical diffusion are greatest, and planktonic foraminifera are distributed more widely throughout the water column; the greatest vertical gradient occurs between the warmest species and the cool ones. When temperatures are uniformly cool, foraminifera clump together, more generalized morphologies and lower diversity prevail.

\section{ZONE-BY-ZONE DISCUSSION OF PALEOCENE ISOTOPIC DATA}

All our isotopic data to date are shown in Table 4. Analyses from Site 384 are supplemented by selected analyses from DSDP Holes 20C, 21, 47.2, 86, 95, 144A, 356, and 357 (see Figure 1 for locations).

\section{Cretaceous/Tertiary Boundary}

Our analyses for benthic foraminifera from the latest Maestrichtian at Site 384 agree well with analyses by Saito and van Donk (1974) for South Atlantic intermediate depth water and Douglas and Savin (1971) for intermediate depth Pacific water, indicating a temperature near or below $10^{\circ} \mathrm{C}$. Our analyses of globotruncanids also correspond well with those of Saito and van Donk (1974); however, all the Paleocene values merit closer examination (Table 6).

Saito and van Donk measured a surface-dwelling latest Cretaceous planktonic, Globotruncana contusa at Site 21 , present latitude $28^{\circ} \mathrm{S}$, and compared this measurement with an early Paleocene Zone P.1 (G. pseudobulloides Zone) value based on mixed planktonics at V22-127 from $41^{\circ} \mathrm{S}$ on the Aghulas Plateau. Between these two sites and times they record a drop in surface temperature across the Cretaceous/Tertiary boundary.

\footnotetext{
${ }^{1}$ The Danian was probably not as "cool" as he imagined!
}

In our opinion although Saito and van Donk have measured latest Cretaceous surface temperatures at $28^{\circ} \mathrm{S}$, they have measured subsurface temperatures in P. 1 at $41^{\circ} \mathrm{S}$. Both the depth and latitudinal differential should (did) look like a temperature drop across the boundary, but was not. The warming from P.1 at V22127 to P.2 at V26-65 they themselves interpret as a latitudinal effect, not necessarily a temperature rise. Again they have not measured surface temperature, but are probably comparing intermediate depth water masses between the two sites.

Douglas and Savin $(1971,1975)$ have two measurements on which they conclude a temperature decline in the Late Cretaceous (primarily in the early Maestrichtian) and an improvement in the early Tertiary (1975, p. 518). Both analyses from Shatsky Rise are mixed planktonics; while the chance of picking surface forms from Maestrichtian faunas, due to the convenience of picking Globotruncana spp. is low, it is highly unlikely that their Paleocene samples from the G. taurica Zone represents surface temperatures. Therefore, the temperature rise they estimate between these two time periods could have been even greater than the $0.3 \%$ they measured.

The key point we wish to make is that Saito and van Donk's P.1 or P.2 measurements or Douglas and Savin's G. taurica measurement do not represent the "climatic amelioration" above the Cretaceous/Tertiary boundary, because the temperature had already risen before the early G. eugubina Zone (Sample 356-29-3, $33 \mathrm{~cm}$ ) some $10^{4}-10^{5}$ years earlier than their measurements. Thus the temperature rise does not occur within the Paleocene, but either at the boundary itself or at the first time it is possible to recognize a Paleocene, e.g., prior to or at the base of the "G." eugubina Zone.

The carbon isotope drop (Sample 29-3, $33 \mathrm{~cm}$ ), then, also would have been coincident with the Cretaceous/Tertiary boundary. We have attempted to show that the carbon isotope trend across the boundary is not an artifact of the particular species analyzed, by taking samples of bulk sediment from the late Maestrichtian and the early Paleocene at Site 384; these samples showed a similar change. (However, only analysis of Sample 356-29-3, $33 \mathrm{~cm}$ can confirm the carbon isotope values, but this analysis remains to be done.) Brenneke and Anderson (1977) have also reported a carbon isotope change in pelagic sediments across the Cretaceous/Tertiary boundary, further supporting our Site 384 data.

In the modern ocean, a carbon isotopic change of that magnitude could only affect the whole mass of oceanic dissolved carbon if essentially the whole of the terrestrial biosphere were put into the ocean (Shackleton, in press). However, if the ocean contained much less dissolved carbon (and calcium) at the end of the Cretaceous as a result of excessive removal in shelf seas, a smaller influx of oxidizing organic carbon would achieve this effect. Shackleton (in press) has argued that very substantial changes in the terrestrial biomass occurred during the Pleistocene, leading to fluctuations in oceanic ${ }^{13} \mathrm{C}$ content. In the Cretaceous a 
TABLE 6

Oxygen Isotopic Data of Latest Cretaceous and Early Paleocene Age From Saito and Van Donk (1974) and Douglas and Savin (1971)

\begin{tabular}{|c|c|c|c|c|c|c|}
\hline Location & Core/Site & Depth $(m)$ & Latitude & Age & \multicolumn{2}{|c|}{${ }_{\delta}^{18} \mathrm{O}$ Measurement } \\
\hline \multicolumn{7}{|l|}{ Saito and van Donk (1974) } \\
\hline Rio Grande Rise & $21,3, \mathrm{CC}$ & $\begin{array}{c}\sim 1500 \\
\text { (back-tracked) }\end{array}$ & $28^{\circ} \mathrm{S}$ & Maestrichtian & $\begin{array}{l}\text { G. contusa } \\
\text { Benthics }\end{array}$ & $\begin{array}{l}-0.73 \\
+1.15\end{array}$ \\
\hline Agh ulas Plateau & V22-127 & $<2900$ & $41^{\circ} \mathrm{S}$ & Early Pliocene & $\begin{array}{l}\text { Mixed planktonics } \\
\text { Benthics }\end{array}$ & $\begin{array}{l}-0.14 \\
+0.42\end{array}$ \\
\hline North of Rio Grande Rise & V26-65 & $<4371$ & $26^{\circ} \mathrm{S}$ & $\mathrm{P} 2-\mathrm{P} 3$ & S. pseudobulloides & -1.00 \\
\hline \multicolumn{7}{|l|}{ Douglas and Savin (1971) } \\
\hline Shatsky Rise & $47.2-12, \mathrm{CC}$ & $<2689$ & $32^{\circ} \mathrm{N}$ & Maestrichtian & Mixed planktonics & -0.63 \\
\hline Shatsky Rise & $47.2-11,3$ & $<2689$ & $32^{\circ} \mathrm{N}$ & $\begin{array}{l}\text { "G." eugubinal } \\
S . \text { pseudobulloides }\end{array}$ & Mixed planktonics & -0.96 \\
\hline
\end{tabular}

large drop in continental plant biomass might have had a drastic effect on terrestrial vertebrate communities while not involving many plant extinctions, just as in the Pleistocene we are more aware of faunal than floral extinctions despite the great distances over which floral communities have been forced to migrate repeatedly.

\section{"Globigerina" eugubina Zone: 64 m.y.}

The sample from Site 384 in this zone is from near its top $(384-13-2,143 \mathrm{~cm})$. Of the three species analyzed, Chiloguembelina midwayensis indicated the highest temperature $\left(\sim 15^{\circ} \mathrm{C}\right)$, with $P$. eugubina and $S$. pseudobulloides indicating slightly lower temperatures. At Site 356 we analyzed a sample from low in the "G." eugubina Zone. The highest temperature was indicated by $G$. cretacea at about $22^{\circ} \mathrm{C}$. Each of three other species analyzed yielded a higher temperature estimate than it did in Sample 384-13-2, $143 \mathrm{~cm}$. This trend of higher temperatures at Site 356 than Site 384 is maintained consistently through the Paleocene.

The carbon isotopic values among the species analyzed in the "G." eugubina Zone yield a trend opposite to that expected; that is, the species registering lighter ${ }^{18} \mathrm{O}$ values, and therefore, presumed to live in warmest water closest to the sea surface, have also the lightest ${ }^{13} \mathrm{C}$ values. This trend is observed at both Site 356 and Site 384 (Figures 6 and 7). There are several possible explanations:

1) dissolved available carbon was isotopically lighter at the sea surface than below it;

2 ) the species analyzed lived below an oxygen-minimum layer in the ocean, in the region where ${ }^{13} \mathrm{C}$ content is expected to increase with depth;

3 ) the order of depth stratification should be taken from the ${ }^{13} \mathrm{C}$ values, implying that subsurface water was warmer (but presumably more saline) than surface water;

4) the species living nearest the surface deposited their carb nate isotopically light with respect to isotopic equilibrium.
The first explanation is difficult to conceive of because it is in the photic zone that the isotopically heaviest carbon is produced through photosynthesis. However, the maximum of photosynthetic activity is in fact not at the ocean surface, but a few meters below it. Thus a foraminifer living in the water column above the layer of most intense photosynthesis could have lighter ${ }^{13} \mathrm{C}$ values than one living a little deeper. Although this is one possible explanation of the data, later in the Paleocene, both at Sites 356 and 384, Chiloguembelina yields lower isotopic temperatures and lighter ${ }^{13} \mathrm{C}$ values than the newly evolved morozovellids (see below). Thus it does not appear that Chiloguembelina was a species adapted to living in the top few meters of the ocean (nor was the morphologically similar Heterohelix in the latest Maestrichtian, accord-

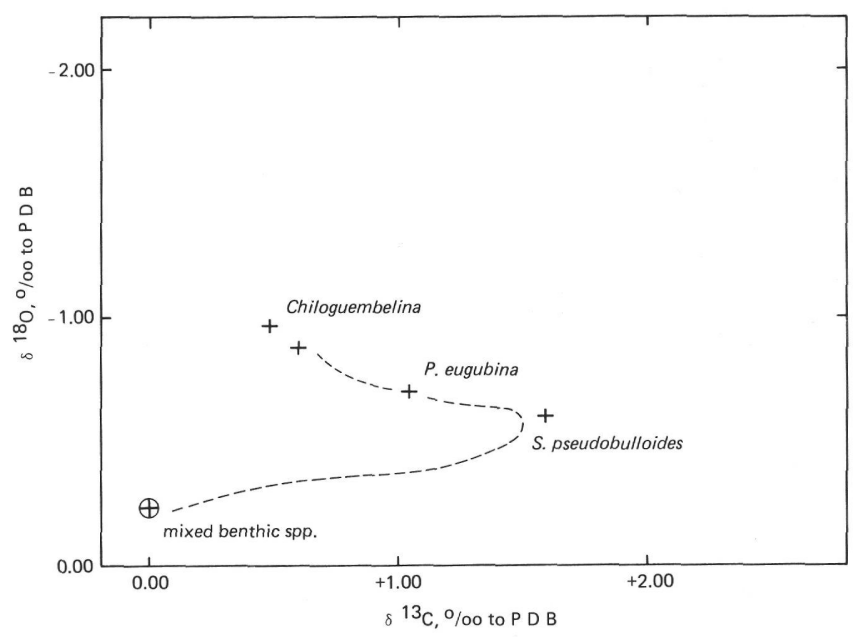

Figure 6. The $\delta^{13} \mathrm{C}$ relationship to $\delta^{18} \mathrm{O}$ among species of planktonic foraminifera from 384-13-2, $143 \mathrm{~cm}$ considered basal Paleocene, top of the "G." eugubina Zone. Among the planktonic species the trend is opposite to that observed in the modern ocean; Chiloguembelina records the warmest temperature, but the lightest carbon values. 


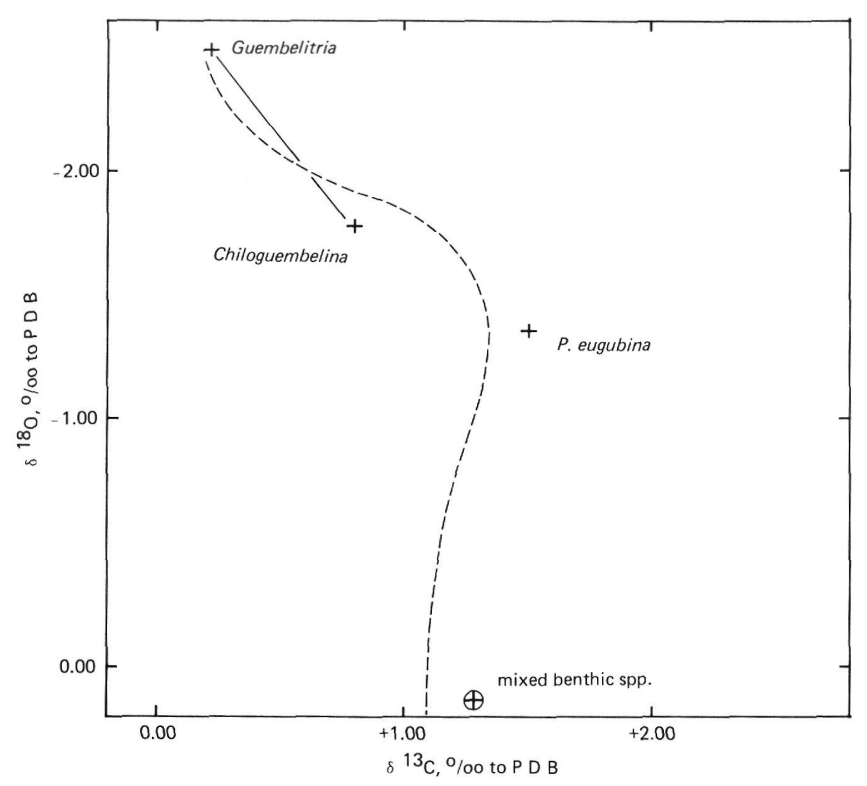

Figure 7. Relationship of carbon isotope to oxygen isotopic ratios from 356-29-3, $33 \mathrm{~cm}$, basal Tertiary, very base of the "G." eugubina Zone. The trend, similar to that in Figure 6, is also opposite to that observed in the modern ocean. Guembelitria, the species living closest to the surface, registers the most negative (lightest) carbon values.

ing to our unpublished data). Furthermore, if Guembelitria, Globoconusa, and Chiloguembelina were occupying this surface layer above the photosynthesis maximum, then it is difficult to explain both the changed habitat of Chiloguembelina above Zone P.1, as well as the loss of any species indicative of that layer after the extinction of Globoconusa and Guembelitria, whose post-Paleocene appearance is first recorded from the Eocene of Trinidad.

It is possible that the oxygen minimum lay at the surface in the Atlantic if the majority of primary production took place not in the sea, but on land. Such a situation seems less likely, but could produce isotopically lighter carbon at the sea surface.

The second explanation is consistent with the position occupied by Chiloguembelina in the water column later in the Paleocene. Although the ${ }^{13} \mathrm{C}$ range in the early Paleocene is greater than is generally found below the oxygen minimum in the modern ocean (about 0.5 per mil at most, Kroopnick, 1974; Duplessy, 1972), it is not beyond reason. According to this explanation, we are not able to estimate surface temperatures in the early Paleocene, but are able to estimate temperatures in the oxygen-minimum zone and below.

The third explanation implies that at both Sites 356 and 384, a subsurface water mass existed that was warmer, and of higher salinity, than the surface water. Surface temperature would be estimated by the oxygen isotopic composition of $P$. eugubina and $S$. pseudobulloides, and the temperature of the high-salinity, low-oxygen content subsurface layer, by the oxygen isotopic composition of $C$. midwayensis and $G$. cretacea. This hypothesis implies a dramatic difference in oceanic circulation patterns compared to those of today. Its support would depend on a demonstration that $S$. pseudobulloides did inhabit water closer to the surface than C. midwayensis. Our data from later in the Paleocene (for example, Samples 356-26-2, $80 \mathrm{~cm}$ in Zone P.2 and 356-24-2, $80 \mathrm{~cm}$ in Zone P.3) do not support this notion; in these samples with clearly developed temperature and ${ }^{13} \mathrm{C}$ stratification, $S$. pseudobulloides clearly registers values indicating a habitat well below the surface. On the other hand, its position with respect to $C$. midwayensis is not entirely clear. We conclude that a temperature inversion is a possible explanation of the data, and that according to this explanation we could not estimate sea surface temperature from the isotopic data until late in Zone P.1. One further ramification of this explanation: these inverted values occur only in parts of the Danian and Oligocene, but not (so far) in the Late Cretaceous or Eocene. Therefore, if a "salinity inversion" occurred it was only for finite time periods and was readily reversible, in the Paleocene at least.

Lastly, it is possible that the genera Guembetitria, Globoconusa, and Chiloguembelina are not recording sea water ${ }^{13} \mathrm{C}$ composition at all, but that like some Recent species such as, Globigerina rubescens, they deposit tests that are isotopically light with respect to isotopic equilibrium for both carbon and oxygen isotopes (Shackleton and Vincent, 1975). However, this explanation is not supported by our data from later in the Paleocene. Through most of the Paleocene $C$. midwayensis clusters in carbon and oxygen isotopic composition with other species along a gradient indicating calcification well below the surface. Moreover, C. midwayensis displays normal ${ }^{13} \mathrm{C}$ composition at Site 384 through Zone P.1, although it continues to register abnormally light values at Site 356 through this zone. This suggests that the values are indicative of an unusual oceanographic situation or habitat of Chiloguembelina rather than of abnormal isotopic fractionation in a particular species.

Although we may not have analyzed foraminifera that lived truly at the sea surface, our data clearly indicate a much warmer surface layer at Site 356 than at Site 384; each species analyzed shows the same feature. The highest temperature, about $22^{\circ} \mathrm{C}$, is indicated by $G$. cretacea at Site 356 , while at Site 384 it is about $16^{\circ} \mathrm{C}$ indicated by $C$. midwayensis. Site 356 was evidently fed by a strong southward-flowing current of warm Tethyan water, while any paleo-Gulf Stream that may have existed did not transport equally warm water to the Grand Banks region of Site 384. This contrast was maintained throughout the Paleocene.

\section{Globorotalia pseudobulloides and G. trinidadensis Zones: 64-61 m.y.}

Many of the samples from this zone display features similar to those from the preceding " $G$ ". eugubina Zone, in particular isotopically light ${ }^{13} \mathrm{C}$ values for the species registering the highest temperatures. However, this situation appears to have been terminated at Site 
356 , so that by Sample $356-26-2,62 \mathrm{~cm}$ a ${ }^{13} \mathrm{C}$ gradient of over 2 per mil exists between Morozovella inconstans (the warmest planktonic) and the benthic species. Data from this and subsequent zones indicate that members of the $M$. inconstans- $M$. uncinata- M. angulata bioseries lived closest to the surface of the species analyzed, judging from both oxygen and carbon isotope data. The carbon isotope differences suggest that the morozovellids did inhabit the photic zone; therefore, we believe that during the remainder of the Paleocene we are estimating sea surface temperature.

The highest temperature recorded for the Paleocene derives from an analysis of $G$. cretacea in the G. trinidadensis Zone (Sample 356-26-6, $80 \mathrm{~cm}$ ). A very high temperature is also recorded by the benthic species in the same sample.

Beginning in the G. trinidadensis zone, a group of species consisting of $S$. pseudobulloides, S. triloculinoides, and $P$. compressa generally register similar oxygen isotope values indicating cool water, and similar carbon isotope values. We interpret these values as describing the water below the surface, and probably below the subsurface oxygen minimum. C. midwayensis indicates similar or slightly higher estimated temperature, but generally a lighter ${ }^{13} \mathrm{C}$ content which suggests that this species inhabited a subsurface oxygen minimum.

Our single sample from Site 47, on the Shatsky Rise and thought to have occupied tropical latitude during the Paleocene, yielded values similar to those obtained by Douglas and Savin (1971), about $2^{\circ} \mathrm{C}$ warmer than the same species at Site 384 and substantially ( $3^{\circ}$ to $4^{\circ} \mathrm{C}$ ) cooler than at Site 356.

\section{Zone P.2: 61-60 m.y.}

In Zone P.2, M. uncinata emerges with the most negative oxygen and the most positive carbon isotope values (Sample 384-11-4, $10 \mathrm{~cm}$ ) (Figure 8). This suggests that $M$. uncinata evolved in surface water in the photic zone.

While the warmest temperature species remain at relatively constant temperatures throughout this interval, the middle depth species appear gradually to change their depth habitat (Figure 5) invading progressively cooler waters even into Zone 3 , when surface waters rise towards a temperature maximum for the post-Danian portion of the Paleocene. As Chiloguembelina continues to register the lowest carbon values, and may be assumed to be inhabiting the oxygen-minimum zone, then the temperature of that zone has decreased during the course of the early and middle $\mathrm{Pa}$ leocene.

\section{Zone P.3: 58-60 m.y.}

At Site 384 , substantially higher temperatures are recorded by the newly evolved Morozovella angulata (Sample 384-11-3, $30 \mathrm{~cm}$ ). In the North Atlantic it appears that surface temperature rose to a peak of nearly $21^{\circ} \mathrm{C}$ early in this zone (probably during the first million years of P.3) and fell thereafter. At Site 356 in the South Atlantic, the highest temperature of close to

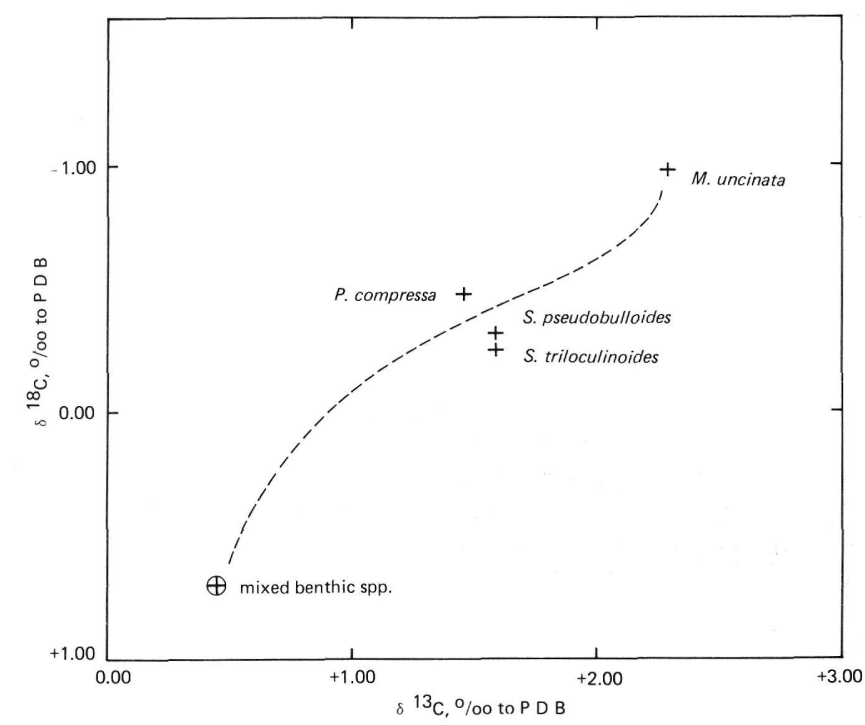

Figure 8. Relationship of carbon isotope to oxygen isotopic ratios for various planktonic foraminiferal species in 384-11-4, $10 \mathrm{~cm}$, planktonic foraminiferal Zone P.2. The between-species variations indicate a $\delta^{13} \mathrm{C}$-depth profile analogous to that in today's ocean.

$24^{\circ} \mathrm{C}$ is also recorded in the oldest samples of Zone P.3 so far analyzed (Sample 25-4, $30 \mathrm{~cm}$ ). Synchronous with these warming temperatures is the vertical extension of planktonic foraminiferal species through the widest temperature range of the entire Paleocene. The increased gradient at this time is caused primarily by the large increase in surface temperature. Separation of the temperature-indicative species groups is more noticeable and distinct at this time, suggesting a more intense thermoclinic barrier between water masses.

Following this basal high, lower temperatures are obtained throughout Zone P.3; the average temperature at Site 384 is close to $17^{\circ} \mathrm{C}$ and at Site $356,20^{\circ} \mathrm{C}$. In samples from higher in this zone $M$. angulata and $M$. conicotruncata record similar temperatures for the surface warm water zone, while $M$. pusilla inhabited markedly cooler water, intermediate between the warmest morozovellids and the cooler temperatures of the low-oxygen group of species. Morozovella pusilla, thus, may have lived below the photic zone, but above the main thermocline at this time.

The one analysis of acarininids, which evolved during this time period, produced a temperature slightly lower than $M$. conicotruncata and nearly equivalent with $M$. angulata. More measurements will have to be made to discern the depth habitats of these forms at their inception.

A clearly recognizable $\delta^{13} \mathrm{C}$ profile is developed at Sites 356, 357, and 384 by this time (Figure 9), so that the warmest species consistently register the highest $\delta^{13} \mathrm{C}$ values and the $\delta^{13} \mathrm{C}$ values decrease (become more negative) with decreasing temperature as one would expect in the Recent ocean (except for the anomalous trend in the oxygen-minimum zone). An increase in the $\delta^{13} \mathrm{C}$ values at the surface can be seen during this time period. 


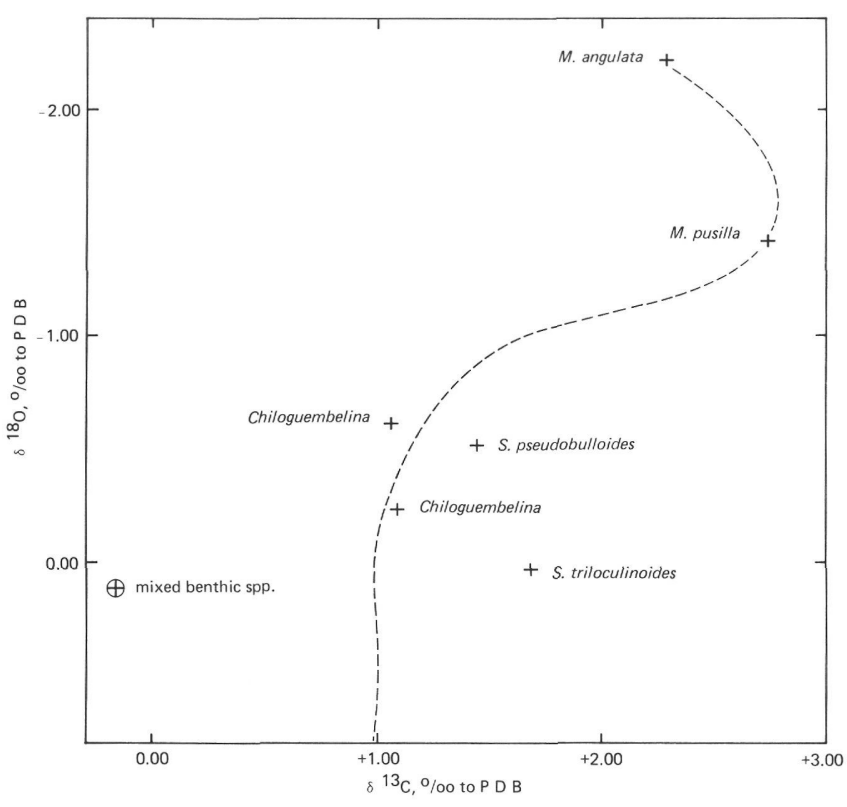

Figure 9. Relationship of carbon isotope to oxygen isotopic ratios in planktonic foraminiferal species from Zone P.3 (383-11-3, $30 \mathrm{~cm})$. The between-species variations imply a $\delta^{13}$ C-depth profile analogous to that observed in the modern ocean.

\section{Zone P.4: 56-58 m.y.}

By the time of Zone P.4 (Cores $384-8$ to 384-6) a temperature drop has been indicated both by the surface-dwelling species (now $M$. velasconensis) and by the intermediate temperature species ( $P$. pseudoscitula, $P$. pseudomenardii, and Subbotina spp.). These lower temperatures persist throughout this zone. Bottom temperatures are relatively low and constantly so during this time interval.

With the expansion of the acarininids at lower latitudes, there are three distinct parcels of foraminifera accentuated: the acarininids and $M$. velascoensis constitute the warmest group; the other morozovellids, the warm group; and all the other species make up the cool group. We believe that the acarininids and morozovellids both lived in the photic zone at this time, while the intermediate forms did not.

In material from late in Zone P.4 (equivalent to nannofossil Zone NP 8) a very intense $\delta^{13} \mathrm{C}$ gradient was developed at the lower latitude Sites 86 and 144. There is a $\delta^{13} \mathrm{C}$ range of nearly $4 \%$ between the warmest and coolest planktonic foraminiferal species. At mid-latitude sites this range is closer to $3 \%$. Values of $\delta^{13} \mathrm{C}$ at the bottom become significantly more positive, particularly at higher latitude sites (assuming that these bottom values are real and not a function of the multispecific analyses). This increased gradient demonstrated both by the widening of the gradient and the shifts in both the bottom and surface values suggests that the oceanic carbon reservoir has shifted in its composition at this time.

Broecker $(1971,1974)$ first drew attention to the potential information in the $\delta^{13} \mathrm{C}$ difference between benthic and planktonic foraminifera as an indication of the nutrient level in the oceans. If his ideas are valid, then this major carbon shift in late Zone P.4 may indicate a profound increase in productivity of the ocean surface water, perhaps as a prelude to the high productivity period resulting in the deposition of seismic horizon $A$. Published values of carbon isotope analyses (Douglas and Savin, 1971) also indicate a shift in the carbon composition of the Pacific Ocean at this same time. Ramifications of such a shift in the carbon partitioning or production rates would be increased circulation vigor at the bottom, an intensified oxygen-minimum zone, and (all other things being equal) a rise in the level of the CCD. Such a rise in the CCD at Site 384 in the Paleocene is suggested by Tucholke and Vogt (this volume). These possibilities will be discussed in more detail elsewhere (Boersma and Shackleton, in preparation).

Nearly consequent with this change in the oceanic carbon, there were extinctions among the intermediate temperature, lower oxygen species of foraminifera $(S$. pseudobulloides and $S$. triloculinoides, and eventually $P$. pseudomenardii). These extinctions may be related to the changing oxygen (nutrient, biotic) content of intermediate depth water masses at this time.

A marked bathymetric and geographic mobility of benthonic foraminifera during the course of the Paleocene has been noticed by Tjalsma and Lohmann (1977). The relatively small changes in bottom temperature we have recorded at Site 384 and several other Atlantic sites suggest that other ecological variables should be used to explain most of this migration among the benthos.

\section{Zone P.5: 56-54 m.y.}

The small amount of data we have for this zone suggests that while bottom temperature remained uncommonly stable through this interval as well as across the Paleocene/Eocene boundary, there was a slight drop in the surface water temperature. The timing of this temperature drop is not certain, but data from Site $20 \mathrm{C}$ suggest that it occurred towards the beginning of the zone. Both the carbon and oxygen values during this zone are most reminiscent of the period from late in Zone P.3 into early Zone P.4.

The stratification of planktonic foraminifera analyzed so far is similar to that late in Zone P.4, with the difference that the lower temperature, lower oxygen group of foraminifera has disappeared, and there are more species of acarininids living in the surface waters.

\section{CONCLUSIONS}

Analysis of the carbon and oxygen isotopic composition of planktonic and benthic foraminiferal carbonate from 200 samples of Paleocene age in the Atlantic Ocean suggests the following.

\section{“G.” eugubina Zone: 64 m.y.}

\section{Temperature}

There was a significant temperature rise across the Cretaceous/Tertiary boundary and these warmer temperatures continued through the basal Tertiary G. eu- 
gubina Zone. Both surface and bottom water temperatures rose by several degrees.

The temperature at DSDP Site 356 in the mid-latitude South Atlantic is significantly warmer at this time than at Site 384 in the mid-latitude North Atlantic. The surface zone waters at Site 356 derive from the warm, trans-Atlantic Tethyan current system. However, the paleo-Gulf Stream also deriving from this Tethyan current system did not bring as warm waters to the Grand Banks region (Site 384) during the Paleocene. (Sites 95 and 86 in the Gulf of Mexico also demonstrate cooler temperatures throughout the Paleocene.) Bottom temperatures at both Sites 356 and 384 (with paleodepth estimates of 2700 and $3700 \mathrm{~m}$, respectively) were around $13^{\circ} \mathrm{C}$ at the base of the Tertiary. These values suggest uniformly warm, deep water throughout the Atlantic.

\section{Foraminifera}

Among the planktonic foraminifera the general order of stratification in the water column (from warmest to coolest) is: Guembelitria cretacea, Chiloguembelina wilcoxensis, Planorotalites eugubina and Subbotina fringa, and finally $S$. triloculinoides (forma minutula). However, the stratification order according to the carbon isotopes is not analogous; species recording the warmest temperatures have the most negative carbon isotope rations (this is the inverse of the situation in the modern ocean). The shape of the carbon isotope curve from surface to bottom resembles that part of the modern carbon isotope curve at and below the oxygen-minimum zone. Therefore we cannot prove that at the beginning of the Tertiary the planktonic foraminifera were living at the ocean's surface.

\section{Zone P.1: 64-61 m.y.}

\section{Temperature}

We cannot confidently specify surface temperatures at this time. The temperature of the oxygen-minimum zone remains relatively unchanged between the " $G$." eugubina Zone and Zone P.1, at around $21^{\circ} \mathrm{C}$. There are two significant temperature rises, reflected primarily in the planktonic foraminifera; the first occurs near the base of this zone when temperatures reach close to $24^{\circ} \mathrm{C}$ at Site 356 . A second rise to closer to $25^{\circ} \mathrm{C}$ occurs towards the top of this zone, also at Site 356.

\section{Carbon}

The carbon profiles of the planktonic foraminifera during most of this time resemble those of the " $G$." $\mathrm{eu}$ gubina Zone. The warmest species have the most negative carbon values. However, by latest $G$. trinidadensis Zone at Site 356 the warmest species have the most positive carbon values.

\section{Foraminifera}

Following a radiation among the planktonic foraminifera through the course of this zone, many new components were added to the spectrum of foraminifera in the water column. In general, morozovellids evolved into warmer, higher oxygen niches, while the subbotinids evolved into intermediate depth, lower oxygen habitats. While Guembelitria continues to record the highest temperatures, the order below becomes more complex: Globoconusa daubjergensis, Planorotalites compressa, Morozovella inconstans, M. trinidadensis, overlie a significantly cooler group composed of Chiloguembelina, Subbotina pseudobulloides, and S. triloculinoides all of which fluctuate in their order at about the same temperatures and oxygen contents.

At this time the foraminifera show the first division into the warmer and cooler groups which become more pronounced later in the Paleocene. Chiloguembelina, Subbotina, and Planorotalites become established as the low-oxygen group by the end of this zone and continue so until their extinctions.

\section{Zone P.2: 61-60 m.y.}

\section{Temperature}

The temperature of the surface and intermediate depth waters remains relatively constant through this time period. Warmest species at Site 384 register temperatures near $16^{\circ} \mathrm{C}$, and nearer $22^{\circ} \mathrm{C}$ at Site 356 . At the Gulf of Mexico Sites 86 and 95 the shallowest species have oxygen isotope ratios close to those at the more northerly Site 384 .

The temperature in the oxygen-minimum zone, derived from Chiloguembelina, fluctuates near $15^{\circ} \mathrm{C}$ in Zone P.2, compared with an average closer to $21^{\circ} \mathrm{C}$ in Zone P.1.

Bottom temperature at all sites varies little through the course of the Paleocene; but in Zone P.2 temperatures were slightly cooler, between $8^{\circ}-10^{\circ} \mathrm{C}$ at intermediate depths (near $3000 \mathrm{~m}$ ).

\section{Carbon}

At this time the warmest foraminiferal species does record the most negative positive carbon values (analogous to the situation in the modern ocean). This suggests that foraminifera are now living in the photic zone of the surface waters.

\section{Foraminifera}

As the warm temperature foraminifera ascended into the photic zone, the intermediate depth species descended into slightly cooler waters, also characterized by the most negative carbon isotope ratios. The extinctions of the warm-temperature, low-oxygen species Guembelitria cretacea and Globoconusa daubjergensis are probably related to the elimination of their very warm, low-oxygen niches.

The generalized order of stratification of planktonic foraminifera is: Morozovella uncinata, M. trinidadensis, Planorotalites compressa, Chiloguembelina wilcoxensis, Subbotina pseudobulloides, and S. triloculinoides. There has been a change in the relative order of depth stratification, as Planorotalites compressa apparently descended to cooler temperatures during this time and became a member of the intermediate depth, low-oxygen group of foraminifera. 
Zone P.3: 60-58 m.y.

Temperature

There is a major rise in surface temperature at the very beginning of this zone (60-59 m.y.) to a high of $24^{\circ} \mathrm{C}$ at Site 356 and close to $22^{\circ} \mathrm{C}$ at Site 384 . Bottom temperatures increase slightly at this time.

Following the initial rise, the latter part of the zone is characterized by markedly cooler surface temperatures, close to $20^{\circ} \mathrm{C}$ at Site 356 and nearer $17^{\circ} \mathrm{C}$ at Site 384. Bottom temperatures drop slightly also. These cooler temperatures characterize the Atlantic through the remainder of the Paleocene.

\section{Carbon}

Foraminifera in the photic zone record more positive $\delta^{13} \mathrm{C}$ values as they did in Zone P.2 and as they continue to do throughout the rest of the Paleocene. There is a noticeable increasing shift in the positive direction in the carbon values, a trend which is finalized in Zone P.4 following.

\section{Foraminifera}

The generalized stratification order reveals that the keeled morozovellids overlie all globigerinid-form species analyzed. This trend is the reverse of the Recent situation where in most instances globigerinid-form species dominate the surface zone and are underlain by globorotaliid-form species. In Zone P.3 Morozovella conicotruncana and Acarinina spp. dominate the warmest waters, below which occur: $M$. angulata, $M$. pusilla, Planorotalites compressa-ehrenbergi, Chiloguembelina, Subbotina pseudobulloides, and S. triloculinoides. It is significant that the first keeled planktonic foraminifera evolved during or after the temperature rise at the base of Zone P.3, not at its inception.

\section{Zone P.4: 58-56 m.y.}

\section{Temperature}

Surface and bottom temperatures fluctuate little through this time; values near $16^{\circ} \mathrm{C}$ at Site 384 and $11^{\circ}-12^{\circ} \mathrm{C}$ at the bottom closely resemble temperatures in the latter part of Zone P.3. Bottom temperatures at Gulf of Mexico Sites 86 and 95 lay close to these North Atlantic values.

\section{Carbon}

The most significant event in the carbon record of the Paleocene is a major excursion in $\delta^{13} \mathrm{C}$ values indicating a shift in the oceanic carbon reservoir late in Zone P.4 (56-57 m.y.). In low latitudes, the carbon gradient among the planktonic foraminifera alone reaches $4 \%$. Especially at higher latitudes, bottom carbon isotopic values become significantly more positive.

At Site 384 in the North Atlantic there is a major change in the percentage of siliceous fossils in the coarse fraction culminating in percentages over 85 per cent in Zone P.4. This is considered a productivity change reflecting an overall increase in surface productivity known to have begun in the later Paleocene at many sites in the Atlantic Ocean. Such productivity changes may be related to the shift in carbon values at this time.

A shift in the carbon reservoir could also produce increased oxygenation of bottom waters, an intensified oxygen-minimum zone, a raising of the CCD, and accompany a major change in the nutrient cycling and/or amounts in the ocean.

\section{Foraminifera}

The generalized stratification order of the planktonic foraminifera of Zone P.4 is identical to that in later Zone P.3. As there are more species of acarininids, the warmest waters include more levels occupied by this group. This occurs without an apparent change in surface water temperature.

Extinctions of the lower oxygen groups of foraminifera are pronounced during this time period and may be related to the carbon shift and its effects on the temperature distribution of low-oxygen niches and their faunal and nutrient compositions.

\section{Zone P.5: 56-54 m.y.}

\section{Temperature}

From the few measurements we have in this zone it appears that there was one temperature decrease early in this time period; subsequently, the temperatures remained relatively cool and constant throughout the remainder of the zone and across the boundary into the earliest Eocene. We record no significant change in bottom or surface temperature across the Paleocene/ Eocene boundary.

\section{Carbon}

While the surface carbon values became slightly less positive, returning to levels characteristic of Zone P.3, the bottom carbon values remained at the more positive levels attained during Zone P.4. The significance of these values is not known, as too few analyses are completed.

\section{Foraminifera}

The stratification order of planktonic foraminifera during this time resembles that in Zone P.4. The new species, Subbotina trilocularis, apparently inhabited the low-oxygen zone along with Chiloguembelina. New species of Morozovella stratify among the pre-existing morozovellids, and below the new and pre-existing acarininids.

\section{ACKNOWLEDGMENTS}

We are grateful to NSF for support under Grants OCE7424110 and OCE76-8300, and to NERC for support under Grant GR3/1762. The manuscript was read by Enrico Bonatti, Bill Berggren, and Isabella Premoli Silva, to whom we are extremely grateful for her continuing collaboration and guidance. We thank Brian Tucholke for making it possible for us to do this work on Site 384, and DSDP for kindly providing samples. 


\section{REFERENCES}

Beckman, J. P., 1957. Chiloguembelina Loeblich and Tappan and foraminifera from the lower Tertiary of Trinidad, B. W. I., U. S. Nat. Mus. Bull. 215, p. 83-93.

Berggren, W. A., 1972. A Cenozoic time-scale some implications for regional geology and paleobiogeography, Lethaia v. 5, p. 195-215.

Boersma, A., 1977. Cenozoic planktonic foraminifera, DSDP Leg 39: South Atlantic. In Perch-Nielsen, K., Supko, P., R., et al., Initial Reports of the Deep Sea Drilling Project, v. 39: Washington (U. S. Government Printing Office), p. $567-590$.

Boersma, A. and Shackleton, N. J., 1977. Tertiary oxygen and carbon isotopic stratigraphy, Site 357 (mid-latitude South Atlantic). In Perch-Nielsen, K., Supko, P. R., et al., Initial Reports of the Deep Sea Drilling Project, v. 39: Washington (U. S. Government Printing Office), p. 911-924.

1978. Oxygen and carbon isotopic record through the Oligocene, DSDP Site 366, Equatorial Atlantic. In Bolli, H. M., Ryan, W. B. F., et al., Initial Reports of the Deep Sea Drilling Project, v. 41: Washington (U. S. Government Printing Office), p. 957-962.

Brenneke, J. C. and Anderson, T. F., 1977. Carbon isotope variations in pelagic sediments, EOS, Trans. Am. Geophys. Union, v. 58 , p. 415.

Broecker, W. S., 1971. A kinetic model of the chemical composition of sea water, Quat. Res., v. 1, p. 188-207.

1974. Chemical oceanography: New York (Harcourt Brace Jovanovich)

Cifelli, R., 1969. Radiation of Cenozoic planktonic foraminifera, Sys. Zool., v. 18, p. 154-168.

Douglas, R. and Savin, S., 1971. Isotopic analyses of planktonic foraminifera from the Cenozoic of the northwest $\mathrm{Pa}$ cific, Leg 6. In Fischer, A. G., Heezen, B. C., et al., Initial Reports of the Deep Sea Drilling Project, v. 6: Washington (U. S. Government Printing Office), p. 11231127.

1973. Oxygen and carbon isotope analyses of Cretaceous and Tertiary foraminifera from the central North Pacific. In Winterer, E. L., Ewing, J. I., et al., Initial Reports of the Deep Sea Drilling Project, v. 17: Washington (U. S. Government Printing Office), p. 591-605.

1975. Oxygen and carbon isotope analyses of Tertiary and Cretaceous microfossils from Shatsky Rise and other sites in the North Pacific Ocean. In Larson, R. L., Moberly, R., et al., Initial Reports of the Deep Sea Drilling Project, v. 32: Washington (U. S. Government Printing Office), p. 509-521.
Duplessy, E., 1972. La géochemie des isotopes stables du carbone dans la mer, CEA-N-1565. Paris (Comm. à l'énergie atomique ).

Emiliani, C., 1954. Depth habitats of some species of pelagic foraminifera as indicated by oxygen isotope ratios, Am. J. Sci., v. 252, p. 149-158.

Frerichs, W. E., 1971. Evolution of planktonic foraminifera and paleotemperatures, J. Paleontol., v. 45, p. 963-968.

Hecht, A. D. and Savin, S., 1971. Oxygen-18 studies of Recent planktonic foraminifera, Science, v. 173, p. 167-169.

Krashenninikov, V. A., 1971. Cenozoic foraminifera. In Fischer, A. G., Heezen, B. C., et al., Initial Reports of the Deep Sea Drilling Project, v. 6: Washington (U. S. Government Printing Office), p. 1055-1069.

Kroopnick, P., 1974. The dissolved $\mathrm{O}_{2}-\mathrm{CO}_{2}{ }^{13} \mathrm{C}$ system in the eastern equatorial Pacific, Deep-Sea Res., v. 21, p. 211 227.

Kroopnick, P., Margolis, P. M., and Wong, C. S., in press. ${ }^{13} \mathrm{C}$ variations in marine carbonate sediments as indicators of the $\mathrm{CO}_{2}$ balance between the atmosphere and the oceans, ONR Conf. on the Fate of Fossil Fuels $\mathrm{CO}_{2}$ in the Oceans.

Loeblich, A. R. et al., 1957. Studies on foraminifera, U.S. Nat. Mus. Bull., 215, p. 1-321.

McGowran, B. 1968. Reclassification of early Tertiary Globorotalia, Micropaleontology, v. 14, p., 179-198.

Premoli Silva, I. and H. Bolli, 1973. Late Cretaceous to Eocene planktonic foraminifera and stratigraphy of the Leg 15 sites in the Caribbean Sea. In Edgar, N. T., Saunders, J. B., et al., Initial Reports of the Deep Sea Drilling Project, v. 15: Washington (U. S. Government Printing Office), p. 499-549.

Shackleton, N. J., in press. Carbon-13 in Uvigerina, tropical rainforest history and the equatorial Pacific carbonate dissolution cycles, ONR Conf. on the Fate of Fossil Fuels $\mathrm{CO}_{2}$ in the Oceans.

Shackleton, N. J. and Kennett, J., 1975. Paleotemperature history of the Cenozoic and the initiation of Antarctic glaciation: oxygen and carbon isotope analyses in DSDP Sites 277, 279, and 281. In Kennett, J. P., Houtz, R. E., et al., Initial Reports of the Deep Sea Drilling Project, v. 29: Washington (U. S. Government Printing Office), p. 743-755.

Shackleton, N. J. and Vincent, E., 1975. Oxygen and carbon isotope studies in Recent foraminifera from the southwest Indian Ocean, Geol. Soc. Am. (abstracts).

Subbotina, N. N. 1953. Globigerinidae, Hantkeninidae, and Globorotalidae, Vses. Neft. Nauchno-Issled. Geol. Razved. Inst. Trudy., n. ser. v. 76, p. 1-296.

Urey, H. C., 1947. The thermodynamic properties of isotopic substances, J. Chem. Soc., p. 562-581. 